UNIVERSIDADE DE SÃO PAULO

CENTRO DE ENERGIA NUCLEAR NA AGRICULTURA

NATÁLIA INAGAKI DE ALBUQUERQUE

Emprego do babaçu (Orbignya phalerata) como fonte energética para catetos (Tayassu tajacu) 


\section{NATÁLIA INAGAKI DE ALBUQUERQUE}

Emprego do babaçu (Orbignya phalerata) como fonte energética para catetos (Tayassu tajacu)

Tese apresentada ao Centro de Energia Nuclear na Agricultura, Universidade de São Paulo, para obtenção do título de Doutor em Ciências.

Área de Concentração: Energia Nuclear na Agricultura Orientador: Prof. Dr. Cyro Ferreira Meirelles

Piracicaba

2006 
AUTORIZO A REPRODUÇÃO E DIVULGAÇÃO TOTAL OU PARCIAL DESTE TRABALHO, POR QUALQUER MEIO CONVENCIONAL OU ELETRÔNICO, PARA FINS DE ESTUDO E PESQUISA, DESDE QUE CITADA A FONTE.

Dados Internacionais de Catalogação na Publicação (CIP)

\section{Seção Técnica de Biblioteca - CENA/USP}

Albuquerque, Natália Inagaki de

Emprego do babaçu (Orbignya phalerata) como fonte energética para catetos (Tayassu tajacu) / Natália Inagaki de Albuquerque; orientador Cyro Ferreira Meirelles. - - Piracicaba, 2006.

79 f.: il.

Tese (Doutorado - Programa de Pós-Graduação em Ciências. Área de Concentração: Energia Nuclear na Agricultura) - Centro de Energia Nuclear na Agricultura da Universidade de São Paulo.

1. Animais silvestres de cativeiro 2. Carcaça 3. Carne 4. Nutrição animal 5. Sustentabilidade I. Título

CDU 599.731.1:636 
FOLHA DE APROVAÇÃO

Natália Inagaki de Albuquerque

Emprego do babaçu (Orbignya phalerata) como fonte energética para catetos (Tayassu tajacu)

Tese apresentada ao Centro de Energia Nuclear na Agricultura, Universidade de São Paulo, para obtenção do título de Doutor em Ciências.

Área de Concentração: Energia Nuclear na Agricultura

Aprovado em:

Banca Examinadora

Prof. Dr.

Instituição:

Assinatura:

Prof. Dr.

Instituição:

Assinatura:

Prof. Dr.

Instituição:

Assinatura:

Prof. Dr.

Instituição:

Assinatura:

Prof. Dr.

Instituição:

Assinatura: 
Ao meu marido Paulo e aos meus

filhos Camila e Felipe, por me amarem tanto e por eu ter sorte de amar e ser amada DEDICO 


\section{AGRADECIMENTOS}

Ao Dr. Cyro Ferreira Meirelles pela atenção, apoio e incentivo antes, durante e após a orientação no curso de doutorado.

Ao Dr. José Aparecido Moreira pela ajuda, orientação e apoio antes e durante a execução do curso de doutorado.

À Dra. Diva Anélie Guimarães pela ajuda, apoio e amizade durante a execução do trabalho de tese.

Ao veterinário MSc. Jurupytan Viana da Silva pela ajuda, dedicação e amizade durante a execução dos experimentos de tese.

Ao Dr. Yvonnick Le Pendu pela amizade e ajuda na administração e manutenção do criatório de catetos.

Ao veterinário MSc. Cristóvão Morelli, à professora MSc. Ana Cássia Ferreira, à doutoranda Patrícia Carvalho de Souza e à mestranda Sylvia Cristina Garcia pela ajuda na coleta de dados no matadouro.

Ao Dr. Irineu Umberto Packer pela ajuda e incentivo na redação da tese

A Dra. Carmem Contreras e ao Dr. Severino Alencar pela ajuda e apoio na execução de trabalhos da tese

A todos os funcionários, de campo e laboratoristas, que direta ou indiretamente contribuíram para a execução do trabalho de tese.

A todos os meus amigos alunos ou não, pela paciência ajuda e incentivo no decorrer das disciplinas e execução do trabalho de tese.

Ao Centro de Energia Nuclear na Agricultura pela oportunidade de realização do curso de doutorado.

Ao Laboratório de Agroindústria, Alimentos e Nutrição da ESALQ por colocar a disposição sua infra-estrutura

À Embrapa Amazônia Oriental por colocar a disposição a área experimental 


\section{RESUMO}

\section{ALBUQUERQUE, N.I.A. Emprego do babaçu (Orbignya phalerata) como fonte}

energética para catetos (Tayassu tajacu). 2006. 80f. Tese (Doutorado) - Centro de Energia Nuclear na Agricultura, Universidade de São Paulo, São Paulo, 2006.

O objetivo deste trabalho foi estudar o emprego de babaçu integral e do seu subproduto (torta de babaçu), como fontes energéticas alternativas substituindo parte do milho na alimentação do cateto em sistemas de produção em cativeiro. $\mathrm{Na}$ primeira fase do trabalho, experimento - I, avaliou-se o desempenho de 12 animais, testando-se o babaçu integral como fonte energética alternativa em substituição ao milho em rações para catetos em fase inicial de reprodução. No experimento - II avaliou-se o desempenho de 12 animais, testando-se a torta de babaçu, e após a fase de terminação os mesmos foram abatidos para análise de suas carcaças e carne. Avaliaram-se parâmetros de carcaça (rendimento, composição corporal, medidas da carcaça, órgãos e glândulas e cortes comerciais). As carnes dos pernis dos animais abatidos foram avaliadas quanto as suas propriedades (perda de peso ao cozimento, força de cisalhamento, $\mathrm{pH}$ e capacidade de retenção de água) e o conteúdo de ácidos graxos. O Ganho diário de peso (GDP) e o consumo diário de ração (CDR) dos animais que receberam níveis crescentes da amêndoa de babaçu integral, diminuiu a medida que a proporção do babaçu integral aumentava, mas até o nível de $25 \%$ de inclusão do mesmo os animais em fase inicial de reprodução conseguiram obter CDR satisfatório. Levando-se em conta a disponibilidade e o custo reduzido do babaçu integral na Amazônia em relação ao milho, sugere-se até o nível de $25 \%$ de babaçu integral em substituição ao milho em rações de catetos em fase inicial de reprodução. Embora não tenham sido observados efeitos 
significativos $(P>0,05)$ dos níveis de torta de babaçu sobre o ganho de peso e consumo diários, os resultados sugerem que, pode-se incluir até o nível de $40 \%$ de torta de babaçu na ração de catetos em fase de terminação, obtendo desempenho satisfatório dos animais. Não foram observados efeitos significativos $(P>0,05)$ dos níveis de torta de babaçu para as variáveis, peso vivo, peso em jejum, carcaça quente, carcaça fria, comprimento, sangue, couro, patas traseiras e patas dianteiras, rendimento de carcaça quente e fria e cortes comerciais. Quanto aos órgãos e glândulas houve efeito quadrático da torta de babaçu no pulmão $(P=0,01)$ e no fígado $(P=0,04)$. Não foram observados efeitos significativos $(P>0,05)$ dos níveis de torta de babaçu para as propriedades da carne, e os ácidos graxos (AG) insaturados (mono e poliinsaturados) foram encontrados em maior quantidade que os ácidos graxos saturados na carne de pernil de catetos. Houve uma tendência para um maior GDP, consumo, bons rendimentos de carcaça e peso de cortes comerciais no nível de inclusão da torta de babaçu até $40 \%$, podendo-se sugerir a mesma como alternativa energética em substituição ao milho em rações para catetos na fase de terminação. Comparando-se a carne de catetos com as carnes de bovinos, ovinos e suínos nota-se que em catetos o teor de AG insaturados (mono e poliinsaturados), foi superior ao de AG saturados, baseando-se na teoria de que os $A G$ poliinsaturados ingeridos na dieta humana são responsáveis por uma redução nos níveis séricos de colesterol, sugere-se.que a carne de catetos é uma fonte alternativa excelente de proteína.

Palavras-chave: Animais silvestres. Carcaça. Carne. Nutrição. Sustentabilidade. 


\begin{abstract}
ALBUQUERQUE, N.I.A. Uses of babassu (Orbignya phalerata) to an energy source for peccaries (Tayassu tajacu). 2006. 80f. Thesis (Doctoral) - Centro de Energia Nuclear na Agricultura, Universidade de São Paulo, São Paulo, 2006.
\end{abstract}

The objective of this work was to study the use of integral babassu and its sub product (babassu meal), as an alternative energy source substituting part of corn on feeding of peccaries in captivity production systems. At the first phase of the work, experiment - I, the performance of 12 animals was evaluated where the integral babassu was tested as an alternative energy source to substitute the corn in maintenance diets. In the experiment - II, the performance of 12 animals was evaluated and the babassu meal was tested as an alternative energy source to substitute the corn in finishing phase diets and after that, the animals were slaughtered to analyze their carcasses and meat. The carcass characteristics were evaluated (dressing percentage, corporal composition, carcass measurements, organs and glands and commercial cuts). The slaughtered animals' ham meats were evaluated on their properties (cooking losses, shear force, $\mathrm{pH}$ and water holding capacity) and the fatty acids contents. The average daily gain and the average daily feed intake of the animals that received crescent levels of the integral babassu, decreased when the proportion of the integral babassu increased, but until the level of $25 \%$ of inclusion of integral babassu the animals on maintenance obtained a satisfactory feed intake. Considering the availability and low costs of the integral babassu in Amazônia beside the corn, it can suggests until the level of $25 \%$ of inclusion of integral babassu in peccaries maintenance diets. Although there were observed no significant differences $(P>0.05)$ of the levels of babassu meal on the 
average daily gain and the average daily feed intake, the results suggested that the inclusion of $40 \%$ of babassu meal in the diet of peccaries in finishing phase obtaining satisfactory development of the animals. There were observed no significant differences $(P>0.05)$ of the babassu meal levels to the variables live weight, fasting weight, hot carcass, cold carcass, length, blood, leather, hind and front feet, hot and cold dressing percentage and commercial cuts. There were a quadratic effect of the babassu meal to the organs and glands on the lung $(P=0.01)$ and on the liver $(P=0.04)$. There were observed no significant differences $(P>0.05)$ of the babassu meal levels for the meat properties and the unsaturated fatty acids (mono and polyunsaturated) were found in more quantity than the saturated fatty acids on the ham meat of peccaries. It seems that there is a tendency for a larger daily weight gain, intake, good dressing percentage and weight of the commercial cuts at the diet until $40 \%$ of babassu meal, then it can recommend the same as an alternative energetic in substitution of corn in diets for peccaries in finishing phase. Comparing the peccary meat with the bovine one, ovine and swine meat, the unsaturated (mono and polyunsaturated) were higher than the saturated fatty acids on the peccary meat, based on the theory that the polyunsaturated fatty acids ingested on the human diet are responsible of one reduction of the seric levels of cholesterol, then it can suggest that the peccary meat is an excellent alternative source of protein.

Key words: Wild Animals. Carcass. Meat. Nutrition. Sustainability. 


\section{LISTA DE ILUSTRAÇÕES}

Figura 1 - Criatório científico de catetos da Embrapa Amazônia Oriental. 19

Figura 2 - Vistas interna e externa das baias experimentais. .27

Figura 3 - Gaiola de transporte para catetos. 34

Figura 4 - Meia carcaça, couro e vísceras de catetos. .35

Figura 5 - Medida de comprimento da carcaça e peso de pernis e costelas de catetos. 35

Figura 6 - Efeito dos níveis de inclusão de babaçu integral na ração sobre o consumo diário de ração de catetos em fase inicial de reprodução.

Figura 7 - Efeito dos níveis de inclusão de torta de babaçu na ração sobre a porcentagem do fígado em relação a carcaça de catetos em fase de terminação.

Figura 8 - Efeito dos níveis de inclusão de torta de babaçu na ração sobre a porcentagem do pulmão em relação a carcaça de catetos em fase de terminação.

Figura 9 - Efeito dos níveis de inclusão de torta de babaçu na ração sobre o peso da gordura de costelas de catetos em fase de terminação.

Figura 10 - Efeito dos níveis de inclusão de torta de babaçu na ração sobre a proporção de matéria mineral nas costelas de catetos em fase de terminação

Figura 11 - Efeito dos níveis de inclusão de torta de babaçu na ração sobre a proporção de matéria mineral nas costelas de catetos em fase de terminação 


\section{LISTA DE TABELAS}

Tabela 1 - Caracterização química em porcentagem dos ingredientes das rações experimentais do experimento - I.

Tabela 2 - Composição percentual das rações do experimento - I.

Tabela 3 - Caracterização química em porcentagem dos ingredientes das rações experimentais do experimento - II. 32

Tabela 4 - Composição percentual das rações do experimento - II. .33

Tabela 5 - Médias de ganho diário de peso (GDP) e consumo diário de ração (CDR) de catetos na fase inicial de reprodução

Tabela 6 - Médias de ganho diário de peso (GDP) e consumo diário de ração (CDR) de catetos na fase de terminação.

Tabela 7 - Médias de componentes da carcaça de catetos abatidos após a fase de terminação. 45

Tabela 8 - Médias de rendimento de carcaça de catetos abatidos após a fase de terminação. 
Tabela 9 - Médias de cortes comerciais retirados da meia carcaça esquerda fria de catetos abatidos após a fase de terminação

Tabela 10 - Médias da porcentagem de órgãos e glândulas em relação a carcaça quente de catetos abatidos após a fase de terminação. 48

Tabela 11 - Médias de características da carne de pernil de catetos abatidos após a fase de terminação. 52

Tabela 12 - Médias das áreas de pico (\%) dos ácidos graxos encontrados na carne de pernil de catetos abatidos após a fase de terminação 55

Tabela 13 - Médias das proporções de ossos, músculo e gordura de costelas de catetos abatidos após a fase de terminação .58

Tabela 14 - Médias das análises químicas bromatológicas de costelas de catetos abatidos após a fase de terminação. 60 


\section{SUMÁRIO}

1 INTRODUÇÃO 13

2 REVISÃO DA LITERATURA

2.1 Considerações gerais sobre o uso da fauna silvestre 15

2.2 Alimentação, nutrição e manejo em cativeiro do cateto 19

2.3 O babaçu como fonte alimentar $\quad 22$

2.4 Carcaça e carne de animais silvestres $\quad 24$

3 MATERIAL E MÉTODOS 27

3.1 Local $\quad 27$

$\begin{array}{ll}3.2 \text { Animais } & 27\end{array}$

3.3 Coleta de dados experimentais $\quad 29$

3.3.1 Experimento - I 30

3.3.2 Experimento - II 31

3.3.3 Avaliação da carcaça $\quad 33$

3.3.4 Análise da carne $\quad 36$

3.3.5 Análise das costelas $\quad 40$

3.4 Delineamento experimental $\quad 40$

4 RESULTADOS E DISCUSSÃO

4.1 Experimento - I 41

4.2 Experimento - II $\quad 43$

4.3 Avaliação da carcaça $\quad 44$

4.4 Análise da carne $\quad 50$

4.5 Análise das costelas $\quad 57$

5 CONCLUSÕES

REFERÊNCIAS $\quad 63$

$\begin{array}{ll}\text { APÊNDICE } & 75\end{array}$ 


\title{
Emprego do babaçu (Orbignya phalerata) como fonte energética para catetos
} (Tayassu tajacu)

\author{
Natália Inagaki de Albuquerque \\ Orientador: Prof. Dr. Cyro Ferreira Meirelles
}

\section{INTRODUÇÃO}

A criação em cativeiro de animais silvestres facilita as pesquisas, em particular a nutrição onde detalhes importantes como o consumo de alimentos, ganho de peso, conversão alimentar, caracterização da carcaça e propriedades da carne ficam difíceis de serem determinados em animais de vida livre. Os estudos em cativeiro indicam e melhoram o potencial da capacidade nutricional, e conseqüentemente a reprodutiva contribuindo para a manutenção da espécie.

Poucos estudos foram realizados até agora em relação aos sistemas de produção de animais silvestres em cativeiro com o objetivo de sustentabilidade. Estes sistemas têm um importante papel na conservação, pois além da caça predatória há mortalidade natural da espécie. Estes sistemas mantêm também a diversidade genética e a estabilidade demográfica em populações submetidas ao manejo.

A fauna silvestre é importante tanto para a alimentação de pequenos agricultores quanto para a formação de florestas através da função de dispersão de sementes (BODMER, 1991). É necessário um uso sustentável deste recurso, ou seja, o consumo deve ser planejado de tal maneira que não se acabe.

Na Amazônia existem alguns projetos, que se apóiam sobre essa filosofia, oferecendo a médio ou longo prazo, métodos alternativos do uso das riquezas 
naturais. A fauna silvestre é um desses recursos naturais, que faz parte da economia na Amazônia, mas que na falta de gerenciamento poderá, ser significativamente reduzida. Mas se for razoavelmente explorada, poderá tornar-se uma fonte de desenvolvimento substancial, que além de fornecer uma fonte alternativa de proteína também poderá ser aproveitada através da utilização de subprodutos animais como gordura, couro, pêlos, etc.

O cateto (Tayassu tajacu) é uma espécie silvestre bastante procurada através da caça, sua alimentação no ambiente natural é basicamente de frutos, folhas e raízes e em cativeiro eles se adaptam facilmente a diferentes tipos de alimentos, podendo ser utilizados grãos, frutos, hortaliças, raízes e forragens, sendo que se adaptam bem com ração comercial de suínos. (ALBUQUERQUE; HUHN, 2001; ALBUQUERQUE et al., 2004b)

A criação em cativeiro de catetos pode tornar-se uma alternativa de sustentabilidade e diversificação de produção de renda de produtores rurais, desde que se utilizem fontes alternativas de alimentos a baixo custo.

O babaçu (Orbignya phalerata) é uma palmeira encontrada em abundância na região Amazônica, que possui alto potencial energético e grau de aproveitamento para algum tipo de utilidade seja na alimentação ou com a finalidade cosmética, sendo que a maioria de suas partes não é aproveitada comercialmente, tornando-se uma fonte alternativa de energia a baixo custo para arraçoamento de animais. (BABAÇU, 2005; BRASIL, 2002).

O objetivo deste trabalho foi estudar o emprego do babaçu integral e seu subproduto (torta de babaçu), como fontes energéticas alternativas substituindo parte do milho na alimentação do cateto em sistemas de produção em cativeiro. 


\section{REVISÃO DE LITERATURA}

\subsection{Considerações gerais sobre o uso da fauna silvestre}

Nos países em desenvolvimento como no caso do Brasil onde a pobreza é ainda uma realidade, mesmo na classe média o consumo anual de alimentos de origem animal é menor do que o consumo mensal das populações de países desenvolvidos da América do Norte e Europa, por isso a má nutrição torna-se comum naqueles e as suas consequências especialmente em crianças são graves. (NRC, 1991).

Segundo o National Research Council (1991), as famílias de baixa renda do meio rural sobrevivem de suas propriedades que consistem de pouco espaço. Cem milhões de produtores dos países do terceiro mundo têm menos de 5 hectares, (50 milhões tem menos de 1 hectare) e suportam em torno de 700 milhões de habitantes, que representam $17 \%$ da população mundial. Por este e por outros motivos deve-se dar mais importância aos animais de pequeno porte. As principais vantagens dos pequenos animais são as seguintes: são mais baratos; os riscos de manutenção são menores, (é mais seguro ter vários pequenos animais do que ter um de grande porte); o retorno de investimento é mais rápido (geralmente quanto menor o animal, maior a capacidade reprodutiva); a flexibilidade é maior para compra e venda dos animais e, pode-se variar o tamanho do rebanho de acordo com a quantidade de alimento disponível. (NRC, 1991).

Os pequenos animais chamados mundialmente de microlivestock são animais de porte pequeno, que incluem os tradicionais, como as aves, suínos, caprinos e ovinos e também espécies silvestres como os roedores (capivara, paca e cutia) e 
ungulados (cateto, veado e queixada), devido sua grande palatabilidade, capacidade reprodutiva e potencial para criação. Estes tipos de animais silvestres promissores para criação foram pesquisados, e em 80 países foram sugeridas mais de 150 espécies animais, sendo que o trabalho se limitou a 40 espécies. (NRC, 1991).

Na Amazônia, a caça de subsistência representa grande proporção da parte protéica da alimentação de famílias rurais (OLIVEIRA; MELO, 1999; ROBINSON; BODMER, 1999; BODMER, 2000; FUCCIO et al., 2003). Nas regiões de colonização antigas e recentes, encontram-se várias espécies silvestres (roedores: paca, cutia e capivara; ungulados: cateto, queixada e veado), cuja única exploração baseia-se na caça, que contribui significativamente para alimentação das populações em particular das mais desfavorecidas, que têm difícil acesso aos produtos comercializados (GUIMARÃES, 1993; VEIGA et al., 1995; BODMER et al., 1997; OLIVEIRA; MELO, 1999). Em certas regiões, a venda de animal de caça em mercados urbanos pode ser uma boa fonte de renda (BODMER et al. 1990, BODMER, 1992, BODMER, 2000). Atualmente o que ocorre é a caça predatória associada à destruição de habitats, que está causando a perda destes recursos naturais. (GUIMARÃES, 1993; NOGUEIRA FILHO, 1999).

A produção de animais silvestres em cativeiro é apontada como uma alternativa racional para o aproveitamento desses recursos, principalmente por beneficiar o meio ambiente evitando a necessidade de desmatamento para que sejam criados animais domésticos (MORAES, 1992; NOGUEIRA FILHO, 1999).

Os agricultores da região Amazônica Brasileira (rodovia Transamazônia-PA) manifestam-se favoravelmente a um manejo mais racional das populações de animais silvestres nas suas comunidades (BONAUDO et al., 2002). Além disso, relata-se freqüentemente pelos agricultores, que os roedores (capivara, cutia, paca) 
ou ungulados (catetos, queixadas, veados) alimentam-se nas áreas de floresta e de capoeiras onde os frutos, folhas e/ou raízes são particularmente procurados, não sendo raro encontrar agricultores, que domesticam jovens animais silvestres.

Bodmer et al. (1999) e Fuccio et al. (2003) relatam, que na Amazônia a maior fonte de proteína consumida está na utilização da caça, em especial os ungulados como o cateto (Tayassu tajacu), o queixada (Tayassu pecari), o veado (Mazama spp.) e a anta (Tapirus terrestris.) sendo que algumas espécies não tem sido mais encontradas no regime alimentar de famílias amostradas na região. Segundo Nepstad et al. (1991) e Bodmer et al. (1999), a ausência destas espécies deve-se ao fato de sua raridade na região que foi fortemente afetada pelo desmatamento.

Bodmer et al (1999) consideram, que a conservação de espécies silvestres in situ somente terá eficácia, se a capacidade biológica das espécies forem garantidas, e incluídas dentro da realidade sócio-econômica de populações rurais, ou seja, que se utilize a fauna sustentavelmente.

Segundo Bonaudo et al. (2002), existe uma demanda para as atividades de criação de animais silvestres em áreas de florestas naturais e de capoeiras em conjunto com comunidades da Amazônia Brasileira (rodovia Transamazônia-PA). Trata-se de oferecer possibilidades alternativas aos agricultores de baixa renda, usando as riquezas naturais de maneira sustentável, diminuindo a pressão da caça sem controle.

Além do enfoque de sustentabilidade, na América Latina, o cateto está entre as espécies mais caçadas para consumo da carne e aproveitamento do couro. $\mathrm{O}$ mesmo tem uma demanda no mercado internacional (Itália, Alemanha e França) onde a pele é processada e chamada de peccary leather para fabricação de artigos de luxo como calçados, luvas, casacos, carteiras e cintos. Estes produtos são, por 
sua vez exportados principalmente para os Estados Unidos e o Japão. (NOGUEIRA FILHO, 1999).

Nogueira Filho et al. (2004a) relatam que além da população de baixa renda existe uma demanda para as populações com alto poder aquisitivo, que possuem o hábito de consumir carnes de animais silvestres, tendo interesse na disponibilidade das mesmas em supermercados e restaurantes.

Quando o assunto é criação em cativeiro, um dos fatores importantes é a sanidade dos animais, que além de poder ser um fator limitante da criação deve-se tomar cuidado com as zoonoses, já que os animais silvestres em geral são portadores naturais.

Silva et al. (2001) realizaram diagnóstico de zoonoses (brucelose, leptospirose e tuberculose) em 41 amostras de soro sanguíneo de catetos originários de vida livre e recém colocados em cativeiro. Os resultados foram todos soro negativos para tuberculose e, somente dois animais machos foram soropositivos para brucelose e quatro para leptospirose, mas que não manifestaram a doença, os autores acreditam que os animais provavelmente foram contaminados em seu habitat de origem.

Albuquerque et al. (2004a) estudando a sanidade de catetos em cativeiro, detectaram as endoparasitoses como sendo o principal controle sanitário necessário para a manutenção do sistema de produção de catetos, sendo que os autores encontraram parasitas semelhantes aos que afetam suínos domésticos. A recomendação do trabalho para controle eficaz é que se realize a vermifugação dos animais de seis em seis meses. Quanto as ectoparasitoses não há a necessidade de controle devido ao hábito comportamental dos catetos de retirada dos ectoparasitas com os dentes. 
2.2 Alimentação, nutrição e manejo em cativeiro do cateto

No Brasil existem alguns criatórios científicos para estudos de espécies silvestres em cativeiro, no caso do cateto (Tayassu tajacu), em Belém-PA na Embrapa Amazônia Oriental (Figura 1) onde se realizam trabalhos de nutrição, reprodução, manejo e comportamento, em Mossoró-RN na Escola Superior de Agricultura de Mossoró e em Ilhéus-BA na Universidade Estadual de Santa Cruz, onde existem alguns trabalhos na área de nutrição e comportamento animal.

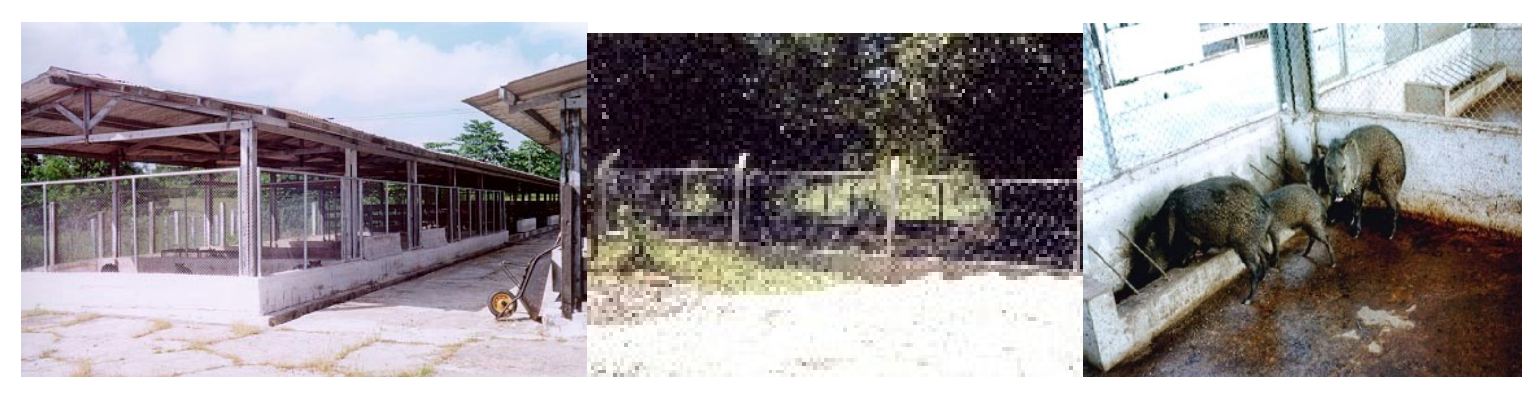

Figura 1. Criatório científico de catetos da Embrapa Amazônia Oriental

Estes sistemas de criações descritos acima, são intensivos e semi-intensivos. O cateto é uma espécie territorial (SOWLS, 1984), ou seja, os indivíduos que não pertencem a um grupo familiar já formado, são perseguidos e podem ser gravemente feridos até causando a morte dos animais. Relatam-se também infanticídios em criações semi-intensivas (PACKARD et al., 1991; NOGUEIRA FILHO, 1992). Entretanto, na criação da Embrapa Amazônia Oriental foram relatados resultados satisfatórios quanto a adaptação de catetos em ambientes reduzidos (baias de 3X12m), (ALBUQUERQUE, 2002; ALBUQUERQUE et 
al.,2004b), assim como na reprodução e na interação comportamental (SILVA et al., 2002; VENTURIERI, 2002; GUIMARÃES et al., 2004; LE PENDU et al., 2004).

Nogueira Filho (1992) relata o balanceamento de uma ração à base de milho e farelo de soja com a qual se conseguiu resultados satisfatórios para a alimentação dos catetos em cativeiro. Segundo levantamento de Nogueira Filho et al. (2004b) em Ilhéus-Bahia, a criação comercial de catetos pode se tornar uma alternativa de diversificação de produção de renda para os produtores rurais desde que se utilizem fontes alternativas de alimentos a baixo custo.

Considera-se que o cateto (Tayassu tajacu) possui um regime alimentar onívoro, que varia em função da disponibilidade de alimentos. Sua alimentação na natureza se baseia principalmente de frutos, folhas raízes e tubérculos, sendo que no Peru já foi observado este animal alimentando-se de fontes protéicas animais. (BODMER, 1990). A Amazônia Peruana possui uma produção frutífera constante ao longo do ano, já na Amazônia Brasileira os frutos são sazonais, estando disponíveis somente em algumas épocas do ano. Este fato provoca uma variação qualitativa da alimentação.

Altrichter et al. (2000) analisando a dieta de catetos e queixadas na Costa Rica, encontrou fragmentos de sementes, frutos e amêndoas, parte vegetativas de plantas e partes de insetos e pequenos animais.

Albuquerque e Huhn (2001) realizaram um trabalho sobre a composição química e o valor nutritivo de frutos, flores e sementes silvestres da Amazônia Brasileira consumidos por catetos em vida livre. Cinqüenta e seis amostras foram testadas e para o extrato etéreo, 19,64\% destacaram-se em gordura e pigmentos, resultando em fonte significativa de energia para compor a dieta dos animais (abacatinho $20,22 \%$, andiroba $15,41 \%$, marfim $14,86 \%$, semente andiroba $40,4 \%$, 
pitomba peluda $12,13 \%$, abiu grande $15,55 \%$, abiu pequeno $18,11 \%$, tanari folha $17,55 \%$, carvão vermelho $13,69 \%$ e frutão $23,29 \%$ ). O rendimento em gordura de $24,53 \%$ das amostras variou de 12,13 a $43,83 \%$. Os maiores valores foram para abacatinho, semente andiroba, cajuzinho, com teores acima de $20 \%$. Das amostras realizadas, 33,9\% apresentaram proteína bruta de 9 a 20,62\% e o cálcio, magnésio e fósforo foram, respectivamente, 0,07 a 0,99, 0,02 a 0,40 e 0,05 a 0,40 \%.

A alimentação básica do cateto no ambiente natural é de frutos, folhas, raízes e tubérculos (SOWLS, 1984; 1997; NOGUEIRA FILHO, 1999) e em cativeiro eles se adaptam facilmente a diferentes tipos de alimentos, sendo normalmente utilizados o milho, mandioca, banana, abóbora e ração comercial de suínos. (NOGUEIRA FILHO, 1999).

Embora o cateto seja da mesma subordem do suíno doméstico (Suiformes), ele pertence a outra família. O suíno doméstico pertence a família Suidae e o cateto a Tayassuidae. Existem três espécies pertencentes à família Tayassuidae: o cateto (Tayassu tajacu), o queixada (Tayassu pecari) e o pecari do Chaco (Catagonus wagneri). (SOWLS, 1984, 1997; MONTGELARD et al., 1998).

Os animais pertencentes a família Tayassuidae como o cateto, possuem um estômago subdividido em compartimentos e devido a este fato alguns autores sugerem que a sua fisiologia digestiva seja semelhante a de ruminantes, e devido as suas necessidades protéicas serem baixas e o seu poder de digestão alto, estes animais conseguem se adaptar bem com alimentos verdes como o pasto (LANGER, 1974, 1979; CARL; BROWN, 1983, 1985; ILSE; HELLGREN, 1995; COMIZZOLI et al., 1997; CAVALCANTE FILHO et al., 1998), mas no ambiente natural somente quando existe escassez de frutos, estes animais passam a se alimentar mais de alimentos verdes. 
Os catetos têm potencial para digerir a fibra alimentar semelhante aos bovinos porque possuem quantidade elevada de microorganismos no estômago causadores de fermentação, sugerindo que este animal utilize a energia de ácidos graxos voláteis. (SANTOS et al., 2004).

O manejo e a reprodução em cativeiro estão diretamente ligados a nutrição, ao desempenho de crescimento e ao tipo de sistema de produção .

O cateto é uma espécie que se reproduz bem em cativeiro (SOWLS, 1984; BARBELLA, 1993; NOGUEIRA FILHO, 1999; ALBUQUERQUE, 2002; SILVA et al. 2002; GUIMARÃES et al., 2004).

Segundo Sowls (1984), os animais ungulados de vida livre da América do Norte, costumam ter uma reprodução sazonal, mas o cateto em cativeiro mostrou ter uma reprodução contínua durante todo o ano, em qualquer época. (SOWLS, 1984; NOGUEIRA FILHO, 1999; SILVA et al. 2002; GUIMARÃES et al., 2004)

A alimentação dos animais tem efeito considerável na reprodução, em especial na freqüência do cio e incidência de gestações. Os animais em vida livre dependem da sazonalidade dos alimentos, que variam ao longo do ano em qualidade nutritiva e em quantidade. (NOGUEIRA FILHO, 1999).

No Texas o índice de nascimentos e a sobrevivência de filhotes estão relacionados com a incidência de chuvas. Nos períodos secos há uma redução no número de filhotes, acredita-se que o motivo seja nutricional, ou seja, em períodos de chuva existe melhores condições alimentares. (SOWLS, 1984)

\subsection{O babaçu como fonte alimentar}


O babaçu (Orbignya phalerata) é uma palmeira originária das regiões norte e nordeste do Brasil, que possui alto potencial energético e um alto grau de aproveitamento, todas as suas partes apresentam algum tipo de utilidade, por exemplo a camada externa e a casca podem ser aproveitadas como fontes alternativas de combustível, suas amêndoas fornecem um óleo muito utilizado na indústria alimentícia (BABAÇU,2005; JOHN DEERE DO BRASIL, 2002; UTILIZAÇÕES DO BABAÇU, 2002). Além disso, a parte fibrosa pode ser utilizada como adubo (BABAÇU, 2005; UTILIZAÇÕES DO BABAÇU, 2002) e suas folhas servem de matéria-prima para a fabricação de utilitários - cestos, abanos, esteiras, janelas, portas etc..., e durante a seca na região nordeste do Brasil essas folhas também servem de alimento para os animais ( BABAÇU, 2005; BRASIL, 2002).

Segundo as pesquisas do Instituto de Recursos Naturais do Maranhão, as amêndoas verdes de babaçu fornecem um leite de propriedades nutritivas semelhantes às do leite humano, sendo que o mesmo é muito utilizado na culinária para tempero de carnes de caça e peixes (BABAÇU, 2005).

Moura et al. (2002) testaram, e comprovaram a eficácia do pó de babaçu obtido do mesocarpo como agente antiulcerogênico, além desta atividade os autores citaram também as atividades antiinflamatórias e antineoplásicas do mesmo.

O óleo de babaçu constitui cerca de $65 \%$ do peso da amêndoa e é um subproduto para a fabricação de sabão, glicerina e óleo comestível, mais tarde transformado em margarina, e de uma torta utilizada na produção de ração animal (BABAÇU, 2005; BRASIL, 2002).

A Embrapa (1991) analisou a composição química da torta de babaçu (subproduto da trituração da polpa de amêndoa de babaçu após o cozimento para extração mecânica do óleo) e comparando o valor nutritivo deste com o milho 
verificaram que a torta de babaçu possui teores mais elevados de proteína bruta, fibra bruta e matéria mineral.

Apesar de tantas e tão variadas utilidades e por sua ocorrência não controlada do ponto de vista econômico e agrícola, o babaçu continua a ser tratado como um recurso marginal, sendo somente uma parte integrante dos sistemas tradicionais e de subsistência (BABAÇU, 2005; UTILIZAÇÕES DO BABAÇU, 2002).

\subsection{Carcaça e carne de animais silvestres}

Os estudos sobre a carcaça e as propriedades da carne de animais silvestres são escassos, embora o mercado consumidor de carne tenha se mostrado bastante receptivo ao consumo deste tipo de alimento.

Existem alguns trabalhos sobre a carcaça de capivaras (Hydrochoeris hydrochaeris hydrochaeris) onde os autores verificaram dados sobre o rendimento de carcaça, as medidas lineares (altura, comprimento e perímetro torácico), a composição física da carcaça e o rendimento de cortes comerciais (ALBUQUERQUE, 1993, BRESSAN et al. 2002) .

Quanto ao cateto, Silva et al. (2002) avaliaram o comprimento da carcaça, rendimentos de carcaça, carne e pernil, bem como a composição químicobromatológica da carne de animais submetidos a dietas com quatro níveis de proteína bruta $(14 \%, 16 \%, 18 \%$ e $20 \%)$.

As características físico-químicas da carne, tais como: brilho, coloração, maciez, suculência e aroma, são parâmetros importantes para o consumidor no momento da compra e determinantes da aceitação global do corte e tipo de carne, além de determinar a freqüência com que o consumidor vai adquirir esse produto. 
Segundo Pino (2005), sabe-se também que nos alimentos os lipídeos afetam as propiedades de textura, suculência, sabor, aroma e cor, sendo um dos responsáveis pela aceitação da carne pelo consumidor. Segundo Oda et al. (2004b), as características de qualidade da carne apresentam variações, que estão relacionadas a vários fatores: método de abate, espécie, idade de abate, peso de abate, sexo, manejo pré-abate e manejo post-mortem. A qualidade ainda varia conforme a região geográfica, as classes sócio-econômicas, as diferentes visões técnico-científicas, industriais, comerciais e questões culturais, entre outros aspectos. Varia também de acordo com as características e preferências individuais de cada consumidor. (ALVARADO HUALLANCO, 2004; CONTRERAS; CUSTODIO, 2002).

Os fatores que interferem na qualidade da carne, também influenciam a extensão e a velocidade da glicólise, bem como o valor de pH final. Em situações anormais, o $\mathrm{pH}$ final de carnes vermelhas pode ser igual ou mais elevado do que 6,2 (escura, firme e ressecada na superfície) e essa carne têm vida-de-prateleira curta. Por outro lado, também em situações anormais, o pH da carne pode apresentar um rápido declínio (valores iguais ou inferiores a 5,8; 1 hora post-mortem) que associado à temperatura de carcaça elevada $\left(36{ }^{\circ} \mathrm{C}\right)$ causa desnaturação protéica, baixa capacidade de retenção de água, coloração pálida e baixa aptidão para a transformação. (ODA et al., 2004b).

fornecimento de dietas com diferentes formulações provoca modificações na composição em ácidos graxos da carne. (PINO, 2005). Os ácidos graxos diferem quanto ao comprimento da cadeia hidrocarbonada, número e tipo de ligações que unem os átomos de carbono, tornando-os de cadeia curta, média e longa, saturados e insaturados. A grande maioria dos ácidos graxos dos lípideos animais tem número par de átomos de carbono. Os principais ácidos graxos saturados da carne são 
palmítico (C16:0), esteárico (C18:0) e mirístico (C14:0). O ácido oleico (C18:1) é o monoinsaturado mais abundante, seguido do palmitoléico (C16:1). Os ácidos linoléico (C18:2), linolênico (C18:3) e araquidônico (C20:4) são os principais ácidos graxos poliinsaturados. Os ácidos graxos saturados e monoinsaturados são os constituintes mais importantes dos triglicerídeos da fração lipídica da carne (RHEE et al., 1988; PINO,2005).

Freire et al., 2000 avaliaram o efeito do sexo e da castração no perfil quantitativo de ácidos graxos e o teor de colesterol na carne de cateto, sendo que os principais ácidos graxos encontrados foram mirístico (1,08 a 1,37\%), palmítico $(21,58$ s $24 \%$, palmitoleico $(2,7$ a $4,1 \%)$, esteárico $(10,59$ a $10,77 \%)$, oleico $(28,37$ a $37,77 \%)$, linoleico $(13,86$ a $22,33 \%)$, linolênico $(0,26$ a $0,67 \%)$ e araquídico $(1,76$ a $3,1 \%)$, encontrando um teor mais alto para ácidos graxos insaturados.

A carne é considerada um alimento nobre para o homem pela qualidade de proteínas, pela presença de ácidos graxos (AG) essenciais e de vitaminas do complexo B. Entretanto, como relatam Oda et al. (2004a), parte dos consumidores associa o consumo da carne vermelha à ocorrência de doenças cardiovasculares. Esses consumidores buscam através da mudança de hábitos no dia a dia, combater o estresse, o sedentarismo e a nutrição desbalanceada, típicos do estilo de vida do homem moderno, que contribuem para o aparecimento da obesidade, hipercolesterolemia e doenças cardiocirculatórias. Segundo Jardim et al (2003) e Oda et al. (2004a), em geral, as carnes de animais silvestres apresentam proporção alta de AG poliinsaturados e teores reduzidos de lipídios totais.

Embora a demanda pela carne de animais silvestres seja elevada a oferta é baixa e instável. Um fator limitante na comercialização da carne de animais silvestres é a falta de estudos das características de qualidade. (ODA et al., 2004a ). 


\section{MATERIAL E MÉTODOS}

\subsection{Local}

Os experimentos de nutrição com a coleta de dados de desempenho dos animais foram realizados nas dependências da Embrapa Amazônia Oriental, Belém - PA, em 12 baias experimentais de $2 \mathrm{~m} \times 6 \mathrm{~m}$, onde foi introduzido 01 animal em cada baia. Cada baia tinha uma fonte de água permanente ou bebedouros, e um comedouro permitindo o livre acesso dos animais à alimentação. (Figura 2)

O abate dos animais foi realizado em abatedouro de suínos localizado no município de Santa Izabel - PA.

As análises nutricionais de composição das rações experimentais e de costelas foram realizadas no Laboratório de Nutrição Animal do CENA-USP, Piracicaba-SP.

As análises da carne, propriedades e ácidos graxos foram realizados no Departamento de Agroindústria, Alimentos e Nutrição da ESALQ-USP, Piracicaba$\mathrm{SP}$.

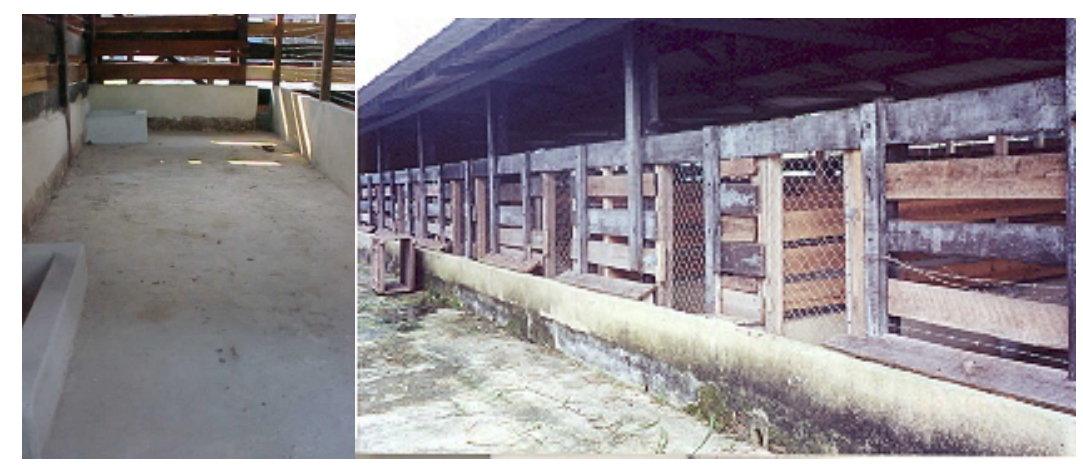

Figura 2. Vistas interna e externa das baias experimentais

\subsection{Animais}


A origem dos animais que foram utilizados nos experimentos foi de catetos nascidos em cativeiro. As primeiras matrizes do criatório foram originárias de mata primária de Uruará-PA e de criatório em cativeiro da Escola Superior de Agricultura de Mossoró - RN. Para evitar consangüinidade foram estabelecidos núcleos familiares com animais provenientes de grupos diferentes, porém de mesma origem geográfica, não havendo cruzamento entre aqueles provenientes de Uruará com os de Mossoró.

No período pré-experimental os animais foram vermifugados, pesados e marcados com um brinco de plástico numerado, esta foi a marcação escolhida por ser a mais eficaz segundo Neal (1958).

No experimento - I foram utilizadas 12 fêmeas no início da fase de reprodução antes de serem cobertas, e no experimento - II 8 fêmeas e 4 machos na fase de terminação, estes animais foram separados em blocos para retirar os efeitos de sexo e peso.

Em todos os experimentos realizados os catetos foram alojados um em cada baia, recebendo a ração correspondente ao tratamento, sendo que as baias e os respectivos tratamentos foram definidos através de sorteio. Os animais permaneceram nas baias por 45 dias em fase de adaptação.

A média dos pesos iniciais dos animais do experimento - I foi de 19,8 kg, com cerca de 12 meses de idade. No experimento - II a média dos pesos iniciais foi de $12,3 \mathrm{~kg}$, os animais estavam com aproximadamente 4 meses de idade, sendo classificados como fase de terminação. Em cada baia, os animais foram pesados mensalmente durante o período experimental para verificar o desempenho através do ganho de peso. Os dados de consumo de ração foram coletados diariamente. 


\subsection{Coleta de dados experimentais}

Foram realizados dois experimentos de nutrição, ambos com o objetivo de estudar fontes alternativas de energia para catetos, substituindo parte do milho em diferentes rações.

No experimento - I utilizou-se níveis crescentes da amêndoa de babaçu integral como fonte energética em substituição ao milho para catetos no início da fase de reprodução. O experimento utilizou um produto de fácil disponibilidade e baixo custo, o que traz benefícios aos pequenos produtores da Amazônia. Sabe-se que, nesta região, o babaçu nasce espontaneamente em pastos sendo considerado em alguns lugares como indesejável.

No experimento - II testou-se níveis crescentes da torta de babaçu em substituição ao milho, em rações formuladas para animais na fase de terminação. A torta é subproduto do babaçu integral, retirado após a extração do óleo e constitui-se como um alimento altamente nutritivo e sub utilizado além de possuir baixo custo.

Os animais do experimento - II após a fase experimental foram abatidos para análise de carcaças e de propriedades da carne.

As rações foram calculadas de acordo com as exigências nutricionais de suínos de baixo potencial genético, nas fases de reprodução (Exp - I) e terminação (crescimento final de catetos) (Exp - II) de acordo com Rostagno et al., 2000.

As fases de coleta de dados foram quatro:

\subsubsection{Experimento - I}

\subsubsection{Experimento - II}

\subsubsection{Avaliação da carcaça}

\subsubsection{Análise da carne}




\subsubsection{Experimento - I}

Durante 120 dias estudou-se o efeito de níveis crescentes da amêndoa de babaçu integral em animais na fase inicial de reprodução (média do peso inicial $19,80 \mathrm{~kg}$ e final $20,14 \mathrm{~kg}$ ). A Tabela 1 mostra a caracterização química e a Tabela 2 a composição percentual dos ingredientes das rações.

As rações foram elaboradas a base de milho e farelo de soja com níveis diferentes de inclusão de babaçu:

TA- Ração controle a base de milho e farelo de soja.

TB- Ração contendo $25 \%$ de amêndoa de babaçu integral e $75 \%$ de milho;

TC- Ração contendo $50 \%$ de amêndoa de babaçu integral e 50\% de milho;

TD- Ração contendo 100\% de amêndoa de babaçu integral e 0\% de milho;

Tabela 1 - Caracterização química em porcentagem dos ingredientes das rações experimentais do experimento - I

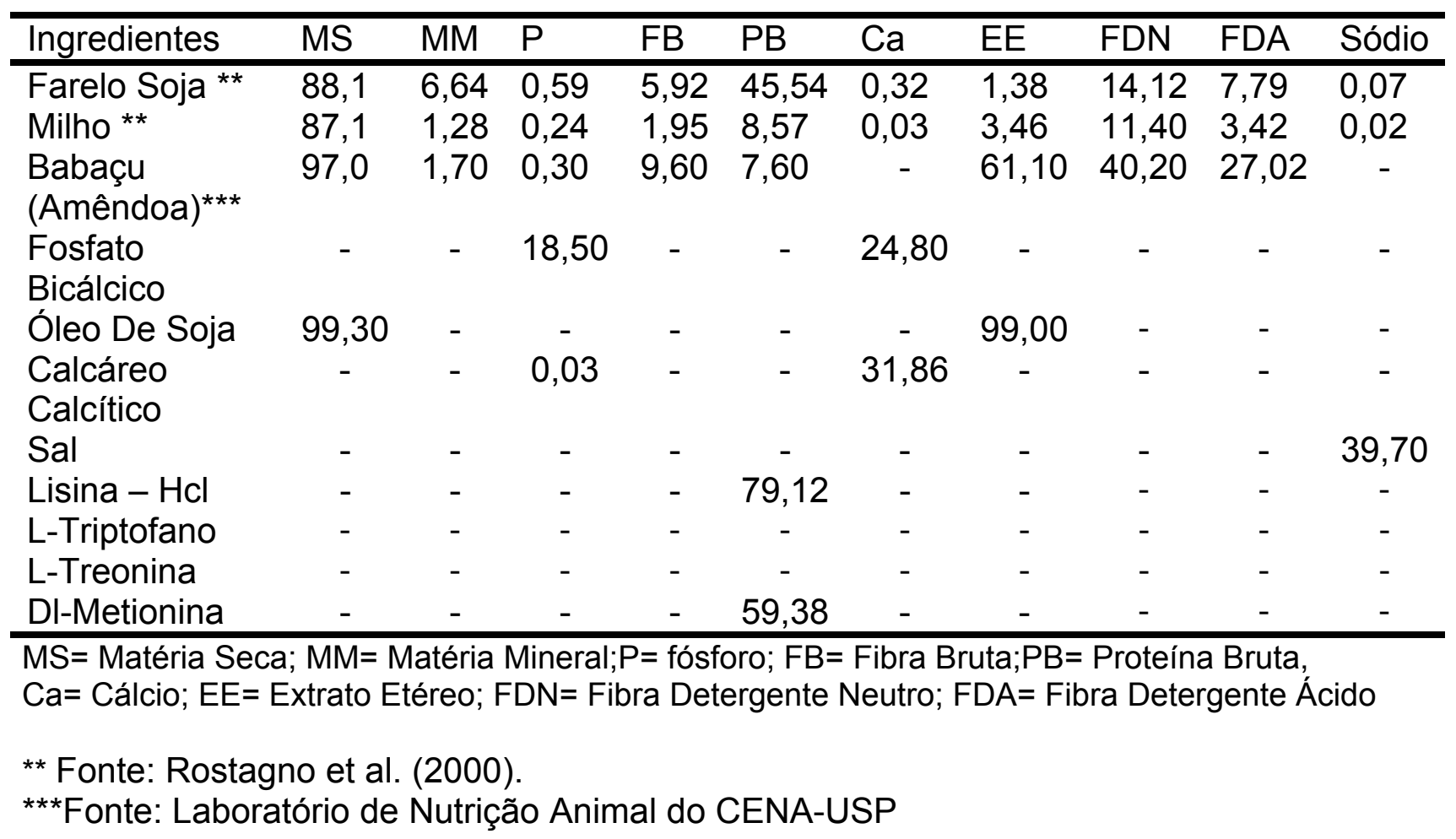


Tabela 2 - Composição percentual das rações do experimento - I

\begin{tabular}{|c|c|c|c|c|}
\hline \multirow{2}{*}{ Ingredientes } & \multicolumn{4}{|c|}{$\begin{array}{c}\text { Níveis de inclusão da amêndoa de babaçu nas } \\
\text { rações }\end{array}$} \\
\hline & $\begin{array}{c}\text { TA } \\
0 \% \text { (basal) }\end{array}$ & $\begin{array}{c}\text { TB } \\
25 \% \\
\end{array}$ & $\begin{array}{c}\text { TC } \\
50 \% \\
\end{array}$ & $\begin{array}{c}\text { TD } \\
100 \% \\
\end{array}$ \\
\hline Babaçu Amêndoa & 0,00 & 20,59 & 41,18 & 82,36 \\
\hline Milho & 82,36 & 61,77 & 41,18 & 0,00 \\
\hline Farelo de Soja & 13,00 & 13,00 & 13,00 & 13,00 \\
\hline Óleo de Soja & 1,00 & 1,00 & 1,00 & 1,00 \\
\hline Fosfato Bicálcico & 1,60 & 1,60 & 1,60 & 1,60 \\
\hline Calcáreo Calcítico & 0,65 & 0,65 & 0,65 & 0,65 \\
\hline Sal & 0,40 & 0,40 & 0,40 & 0,40 \\
\hline Lisina $-\mathrm{Hcl}$ & 0,30 & 0,30 & 0,30 & 0,30 \\
\hline Dl-Metionina & 0,08 & 0,08 & 0,08 & 0,08 \\
\hline L. Triptofano & 0,02 & 0,02 & 0,02 & 0,02 \\
\hline L. Treonina & 0,09 & 0,09 & 0,09 & 0,09 \\
\hline Suplemento Vitamínico ${ }^{a}$ & 0,40 & 0,40 & 0,40 & 0,40 \\
\hline Suplemento Mineral $^{\mathrm{b}}$ & 0,10 & 0,10 & 0,10 & 0,10 \\
\hline Total & 100,00 & 100,00 & 100,00 & 100,00 \\
\hline \multicolumn{5}{|l|}{ Valores Calculados*: } \\
\hline Energia Digestível, $\mathrm{Kcal}^{-1}$ & 3309 & 3309 & 3309 & 3309 \\
\hline Proteína Bruta, \% & 13,71 & 13,71 & 13,71 & 13,71 \\
\hline Cálcio, \% & 0,69 & 0,69 & 0,69 & 0,69 \\
\hline Fósforo Total, \% & 0,57 & 0,57 & 0,57 & 0,57 \\
\hline Fósforo Disponível, \% & 0,32 & 0,32 & 0,32 & 0,32 \\
\hline Lisina, \% & 0,71 & 0,71 & 0,71 & 0,71 \\
\hline Metionina+Cistina, \% & 0,49 & 0,49 & 0,49 & 0,49 \\
\hline Treonina, \% & 0,50 & 0,50 & 0,50 & 0,50 \\
\hline Triptofano, \% & 0,13 & 0,13 & 0,13 & 0,13 \\
\hline Sódio, \% & 0,15 & 0,15 & 0,15 & 0,15 \\
\hline
\end{tabular}

${ }^{a}$ Quantidades por kg de ração: vitamina A, 625000Ul; vitamina D3, 125000Ul; vitamina E, $3375 \mathrm{UI}$; ácido fólico, $875 \mathrm{mg}$; biotina, 27,56mg; cloreto de colina, $2475 \mathrm{mg}$; niacina, $4000 \mathrm{mg}$; ácido pantotênico, $2000 \mathrm{mg}$; tiamina, $175 \mathrm{mg}$; riboflavina, $550 \mathrm{mg}$; piridoxina, $175 \mathrm{mg}$; vitamina B12, 2800mg; antioxidante, 200mg.

b Quantidades por kg de ração: Ferro, 22000mg; cobre, 5000mg; zinco, 18750mg; manganês, $12500 \mathrm{mg}$; iodo, 238mg; selênio, 56,3mg; cobalto, $116 \mathrm{mg}$;

* Valores calculados de acordo com as exigências nutricionais para suínos de baixo potencial genético na ração basal (ROSTAGNO et al., 2000)

\subsubsection{Experimento - II}


Durante 116 dias pesquisou-se o efeito de níveis crescentes da torta de babaçu (subproduto resultante da trituração da polpa da amêndoa de babaçu após o cozimento para a extração mecânica do óleo) sobre o crescimento e desenvolvimento de catetos em fase de terminação (média do peso inicial de 12,33 $\mathrm{kg}$ e final de $16,25 \mathrm{~kg})$.

A Tabela 3 mostra a caracterização química e a Tabela 4 a composição percentual dos ingredientes das rações do experimento - II. As rações foram elaboradas a base de milho e farelo de soja com níveis diferentes de inclusão da torta de babaçu:

TA- Ração controle a base de milho e farelo de soja;

TB- Ração contendo $20 \%$ de torta de babaçu e $80 \%$ de milho;

TC- Ração contendo $40 \%$ de torta de babaçu e $60 \%$ de milho;

TD- Ração contendo $60 \%$ de torta de babaçu e $40 \%$ de milho.

Tabela 3 - Caracterização química em porcentagem dos ingredientes das rações experimentais do experimento - II

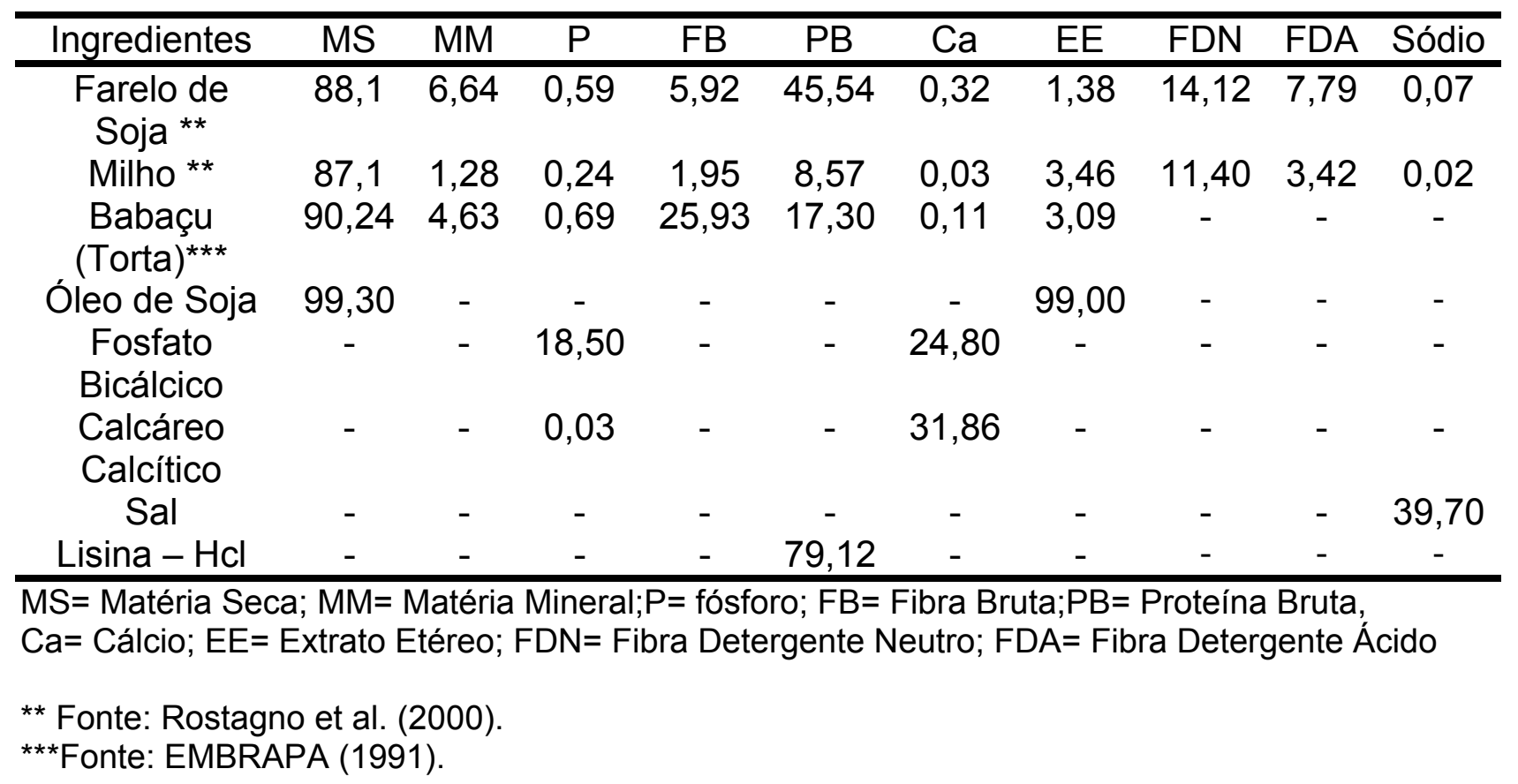


Tabela 4 - Composição percentual das rações do experimento - II

\begin{tabular}{|c|c|c|c|c|}
\hline \multirow[b]{2}{*}{ Ingredientes } & \multicolumn{4}{|c|}{ Níveis de inclusão da torta de babaçu nas rações } \\
\hline & $\begin{array}{c}\text { TA } \\
0 \% \text { (basal) }\end{array}$ & $\begin{array}{c}\text { TB } \\
20 \%\end{array}$ & $\begin{array}{c}\text { TC } \\
40 \%\end{array}$ & $\begin{array}{c}\text { TD } \\
60 \%\end{array}$ \\
\hline Babaçu (Torta) & 0,00 & 15,66 & 31,33 & 46,99 \\
\hline Milho & 78,32 & 62,66 & 46,99 & 31,33 \\
\hline Farelo de Soja & 14,60 & 14,60 & 14,60 & 14,60 \\
\hline Óleo de Soja & 1,00 & 3,50 & 3,50 & 3,50 \\
\hline Fosfato Bicálcico & 1,25 & 1,25 & 1,25 & 1,25 \\
\hline Calcáreo Calcítico & 0,78 & 0,78 & 0,78 & 0,78 \\
\hline Sal & 0,40 & 0,40 & 0,40 & 0,40 \\
\hline Lisina - Hcl & 0,15 & 0,00 & 0,00 & 0,00 \\
\hline Suplemento Vitamínico ${ }^{a}$ & 0,40 & 0,40 & 0,40 & 0,40 \\
\hline Suplemento Mineral ${ }^{\mathrm{b}}$ & 0,10 & 0,10 & 0,10 & 0,10 \\
\hline Inerte & 3,00 & 0,65 & 0,65 & 0,65 \\
\hline Total & 100,00 & 100,00 & 100,00 & 100,00 \\
\hline Valores Calculados*: & & & & \\
\hline Energia Digestível, $\mathrm{Kcal}^{-1}$ & 3304 & 3304 & 3304 & 3304 \\
\hline Proteína Bruta & 13,49 & 13,49 & 13,49 & 13,49 \\
\hline Cálcio & 1,19 & 1,19 & 1,19 & 1,19 \\
\hline Fósforo Total & 0,78 & 0,78 & 0,78 & 0,78 \\
\hline Fósforo Disponível & 0,53 & 0,53 & 0,53 & 0,53 \\
\hline Lisina & 0,49 & 0,49 & 0,49 & 0,49 \\
\hline Metionina+Cistina & 0,41 & 0,41 & 0,41 & 0,41 \\
\hline Treonina & 0,41 & 0,41 & 0,41 & 0,41 \\
\hline Triptofano & 0,11 & 0,11 & 0,11 & 0,11 \\
\hline Sódio & 0,19 & 0,19 & 0,19 & 0,19 \\
\hline
\end{tabular}

${ }^{a}$ Quantidades por kg de ração: vitamina A, 625000Ul; vitamina D3, 125000Ul; vitamina E, $3375 \mathrm{UI}$; ácido fólico, $875 \mathrm{mg}$; biotina, $27,56 \mathrm{mg}$; cloreto de colina, $2475 \mathrm{mg}$; niacina, $4000 \mathrm{mg}$; ácido pantotênico, $2000 \mathrm{mg}$; tiamina, $175 \mathrm{mg}$; riboflavina, $550 \mathrm{mg}$; piridoxina, $175 \mathrm{mg}$; vitamina B12, 2800mg; antioxidante, 200mg.

b Quantidades por kg de ração: Ferro, 22000mg; cobre, 5000mg; zinco, 18750mg; manganês, $12500 \mathrm{mg}$; iodo, $238 \mathrm{mg}$; selênio, $56,3 \mathrm{mg}$; cobalto, $116 \mathrm{mg}$;

* Valores calculados de acordo com as exigências nutricionais para suínos de baixo potencial genético na ração basal (ROSTAGNO et al., 2000)

\subsubsection{Avaliação da carcaça}


Ao final da fase experimental quando os animais utilizados no experimento - II atingiram o peso de abate (média de 16,25 kg e 7 meses de idade), foram pesados, e após 24 horas de jejum foram pesados novamente, e enviados ao abatedouro. Do criatório até o abatedouro foram cerca de 2 horas de viagem, como eram animais silvestres houve a necessidade de cuidados especiais como a aquisição de licença para o transporte e abate, a construção de gaiolas em madeira (Figura 3), a escolha do horário no início da manhã e a diminuição do stress através do resfriamento dos animais com jatos de água minimizando os efeitos do calor (Figura 3).

As características de carcaça foram avaliadas, utilizando parte da metodologia de classificação de carcaças adotada pela Associação Brasileira de Criadores de Suínos (1973). Estudaram-se os efeitos das rações utilizadas no experimento - II nos parâmetros de carcaça (rendimento, composição corporal, medidas da carcaça, órgãos e glândulas).

No abatedouro, eles foram atordoados, sangrados, e seus couros foram retirados e pesados, as carcaças foram serradas longitudinalmente ao meio, e as vísceras e os rins foram retirados. (Figura 4).

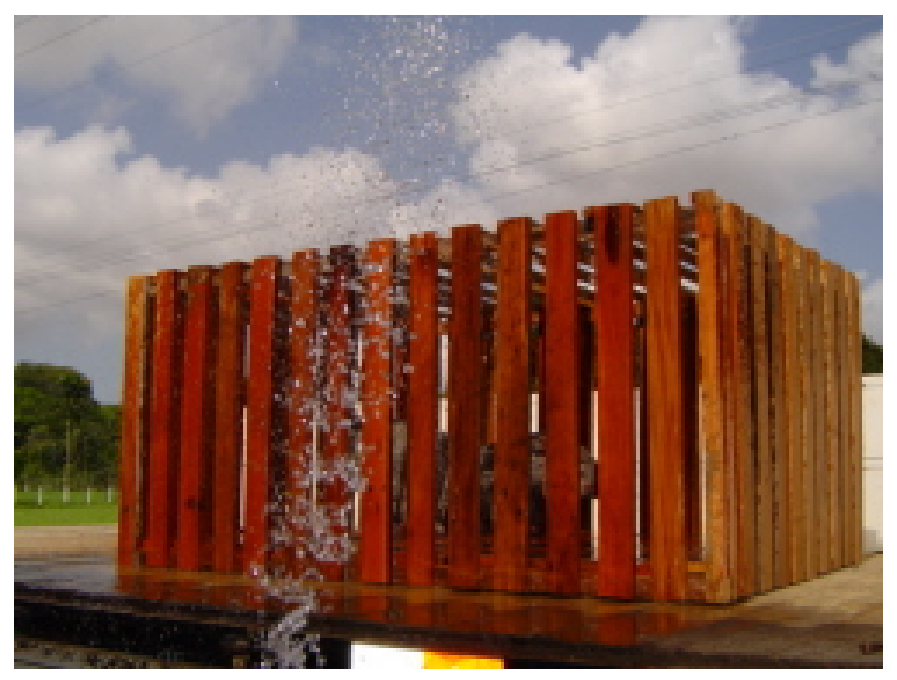

Figura 3. Gaiola de transporte para catetos 


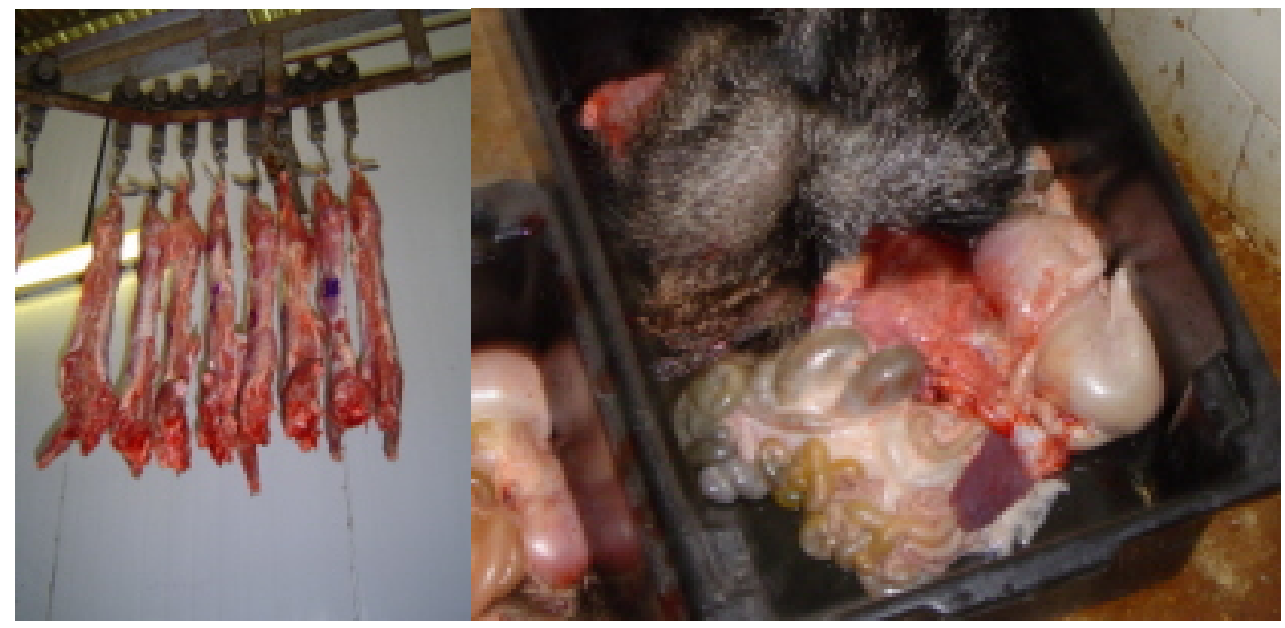

Figura 4. Meia carcaça, couro e vísceras de catetos

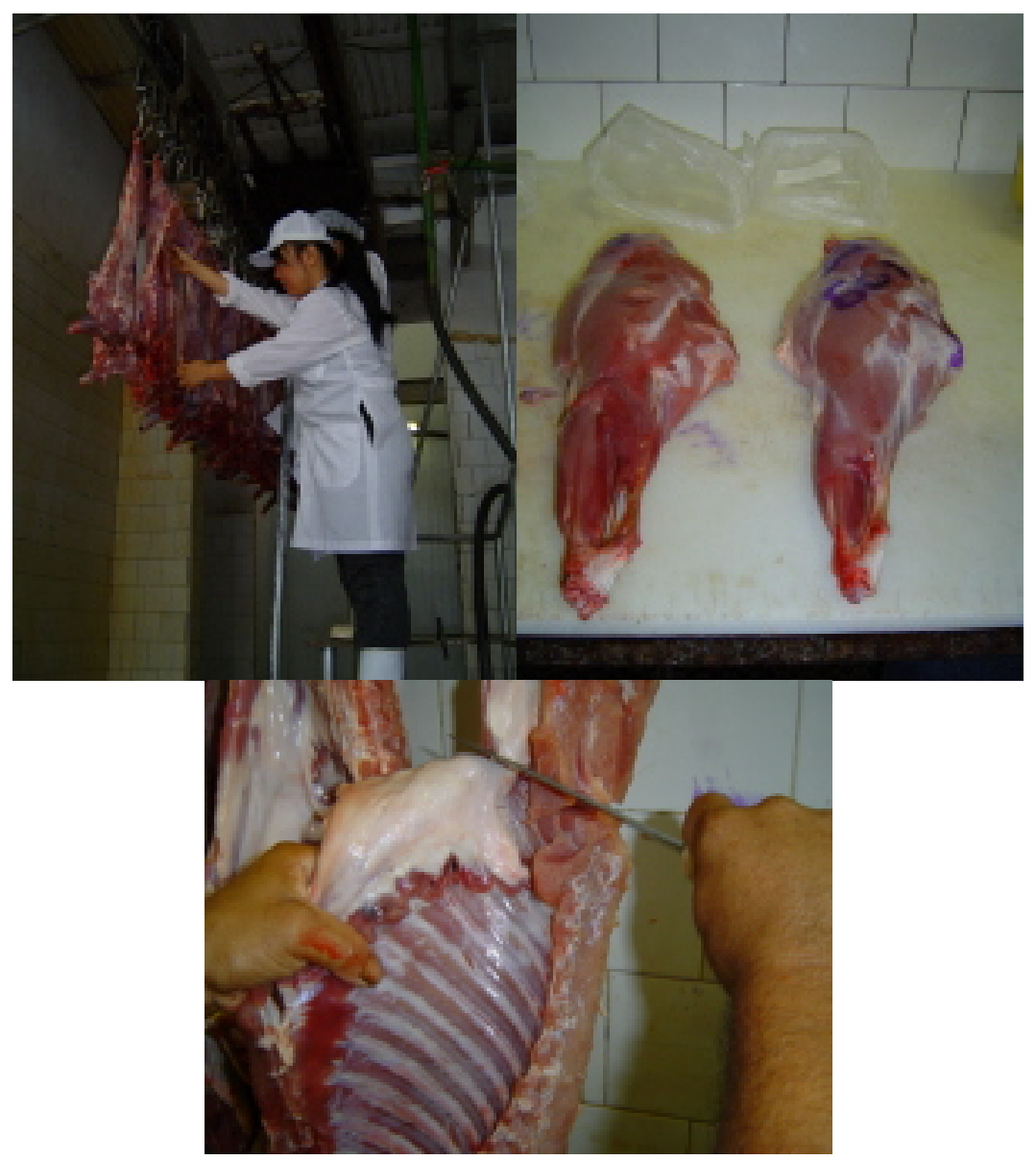

Figura 5. Medida de comprimento da carcaça e peso de pernis e costelas de catetos 
As duas meias carcaças foram identificadas, pesadas e acondicionadas em uma câmara fria, onde permaneceram pelo tempo aproximado de 24 horas, a uma temperatura de 2 a $4{ }^{\circ} \mathrm{C}$. Após este período de refrigeração as duas meias carcaças foram pesadas, e as seguintes medidas e cortes foram feitas:

a) Comprimento de carcaça (CC), medida que compreende o espaço entre o bordo cranial da sínfise pubiana ao bordo cranial ventral do Atlas. (Figura 5).

b) Peso do pernil (Figura 5).

c) Peso das costelas (Figura 5)

d) Peso das paletas

e) Peso das patas dianteiras e traseiras

f) Peso dos órgãos e glândulas

A partir desses dados foram feitos os seguintes cálculos:

a) Rendimento de carcaça quente $(R C Q)=$ razão entre o peso da carcaça quente e o peso em jejum, dado em porcentagem

b) Rendimento de carcaça fria $(\mathrm{RCF})=$ razão entre o peso da carcaça fria e o peso em jejum, dado em porcentagem

c) Porcentagem do pernil = razão entre o peso do pernil e o peso da $1 / 2$ carcaça correspondente, cortada ao meio.

\subsubsection{Análise da carne}

As carnes dos pernis dos animais abatidos foram conservadas em gelo, e transportadas logo após o abate para Piracicaba-SP, para serem avaliadas quanto as suas propriedades (atributos de qualidade) e o conteúdo de ácidos graxos. Os itens analisados foram os seguintes: 
a) Perda de peso por cozimento

A determinação da perda de peso por cozimento foi realizada pelo registro dos pesos das amostras antes e após o cozimento seguindo a metodologia de Hanikel (1998).

Um total de 24 amostras com uma repetição de cada tratamento pesando 300 $\mathrm{g}$, de cada corte de pernil foram colocadas a $+4{ }^{\circ} \mathrm{C}$ durante 12 horas. Os pernis foram cortados em um formato $(6 \times 4 \times 8 \mathrm{~cm})$, pesados, e embalados a vácuo. As amostras foram então mantidas por 90 minutos em um banho de água a $70{ }^{\circ} \mathrm{C}$, até atingir uma temperatura interna de $69-70{ }^{\circ} \mathrm{C}$ para esse tamanho de amostra. (HANIKEL, 1998). Posteriormente, as amostras foram resfriadas dentro do saco em baixo de água corrente. A superfície é enxaguada, e enxugada com papel e as amostras foram pesadas novamente, para calcular a perda de peso no cozimento através da diferença entre o peso inicial e final expressa em porcentagem.

b) Força de cisalhamento

Foi determinada por meio de um analisador de textura Textuômetro Texture Test System marca FTC, modelo TP2, acoplado com acessório tipo WarnerBratzler, com velocidade de $20 \mathrm{~cm} / \mathrm{seg}$.

Seguindo a metodologia de Hanikel (1998), um total de 24 amostras com uma repetição de cada tratamento pesando $300 \mathrm{~g}$, de cada corte de pernil foram colocadas a $+1{ }^{\circ} \mathrm{C}$ durante 12 horas. As amostras foram colocadas em uma embalagem específica para suportar altas temperaturas, CN-530/CN-590 the Cryovac Sealed Air Corporation e foram mantidas por $90 \mathrm{~min}$ em um banho de água a $70{ }^{\circ} \mathrm{C}$. Posteriormente foram resfriadas dentro do saco em banho de água 
corrente, e logo após foram esfriadas e armazenadas por 24 horas a $5^{\circ} \mathrm{C}$. Para cada amostra cozida obteve-se em média 9 tiras retangulares com uma seção cruzada de $100 \mathrm{~mm}^{2}$ (10X10 mm), e com a direção da fibra paralela a uma dimensão longa de $30 \mathrm{~mm}$ foi medida. Os resultados foram expressos em $\mathrm{kgf.} \mathrm{cm}^{-2}$.

c) Capacidade de retenção de água (CRA)

Utilizou-se a metodologia descrita por Nakamura \& Katoh (1985), que se baseou na pesagem acurada de aproximadamente $1 \mathrm{~g}$ de carne crua em papel filtro, e colocou-as em centrífuga a 1500 G por um período de tempo de 4 minutos. Após centrifugação, a amostra foi pesada e em seguida colocada na estufa a $70{ }^{\circ} \mathrm{C}$ durante 12 horas. $\mathrm{O}$ valor de CRA foi determinado pela diferença entre o peso da amostra após centrifugação e o peso da amostra seca, dividida pelo peso final sendo o valor expresso em porcentagem. O número de amostras utilizado foi 2 por cada corte (uma repetição) com um total de 24 amostras de corte de pernil.

d) $\mathrm{pH}$

Utilizou-se um total de 24 amostras com uma repetição para cada corte de pernil. A medição foi feita num potenciômetro digital marca Digimed DM2, com eletrodo de punção. As medições foram tomadas em quatro pontos nos músculos de pernis de catetos. A carne dos pernis foi analisada após 24 horas do abate.

e) Perfil de ácidos graxos

A extração dos lipídios da carne dos pernis de catetos foi realizada de acordo com a metodologia de Bligh e Dyer (1959), segundo algumas modificações propostas por Christie (1982) e Smedes e Thomasen (1996). Foram pesados $10 \mathrm{~g}$ 
da amostra úmida triturada (com cerca de $70 \%$ de umidade), e o tecido foi homogeneizado durante 5 minutos com uma mistura de $10 \mathrm{~mL}$ de clorofórmio e $20 \mathrm{~mL}$ de metanol em uma mesa agitadora. Em seguida, foram adicionados mais 10 $\mathrm{mL}$ de clorofórmio, e procedeu-se a agitação por mais 5 minutos. A mistura foi filtrada, e o resíduo do papel de filtro foi lavado com mais $10 \mathrm{~mL}$ de clorofórmio para um melhor rendimento da extração. O filtrado foi transferido para um funil de separação de $250 \mathrm{~mL}$, adicionado de $10 \mathrm{~mL}$ de solução de $\mathrm{KCl}$ 0,88\% e agitado vigorosamente. Formou-se um sistema bifásico e a fase inferior, contendo os lipídios purificados diluídos em clorofórmio, foi filtrada em papel de filtro contendo sulfato de sódio anidro e coletada em balão volumétrico previamente pesado. O solvente foi totalmente evaporado utilizando-se gás nitrogênio.

O óleo extraído da carne dos pernis foi esterificado e metilado de acordo com a metodologia de Hartman e Lago (1973). Foram pesados 100-200 mg de óleo em frascos de $50 \mathrm{~mL}$ providos de condensador para saponificação com $5 \mathrm{~mL}$ de solução metanólica $0,5 \mathrm{M}$ de $\mathrm{KOH}$ sob fervura. Adicionaram-se $15 \mathrm{~mL}$ do reagente de esterificação à solução quente e a mistura foi aquecida sob refluxo por 3 minutos. Em seguida, transferiu-se a amostra para um funil de separação usando $25 \mathrm{~mL}$ de éter de petróleo e $50 \mathrm{~mL}$ de água destilada. A fase inferior, aquosa, foi descartada e a fase etérea foi lavada duas vezes com $25 \mathrm{~mL}$ de água. As amostras foram então transferidas para frascos âmbar e tampados e guardadas a $-18^{\circ} \mathrm{C}$ até o momento da injeção em cromatógrafo gasoso.

Para determinação do perfil de ácidos graxos nas amostras metiladas foi usado um cromatógrafo gasoso (Hewlett 5890 Series II) com detector FID (flame ionization detector) e coluna capilar de sílica de $60 \mathrm{~m} \times 0,25 \mathrm{~mm} \times 0,25 \mu \mathrm{m}$ (DB 23). As condições de injeção foram: temperatura do forno a $130{ }^{\circ} \mathrm{C}$ por 1 minuto, 130 
${ }^{\circ} \mathrm{C}$ a $170{ }^{\circ} \mathrm{C}$ (taxa de $6,5{ }^{\circ} \mathrm{C} / \mathrm{min}$ ), de $170{ }^{\circ} \mathrm{C}$ a $215^{\circ} \mathrm{C}$ (taxa de $\left.2,75^{\circ} \mathrm{C} / \mathrm{min}\right), 215$ ${ }^{\circ} \mathrm{C}$ por 12 minutos, de $215{ }^{\circ} \mathrm{C}$ a $230{ }^{\circ} \mathrm{C}\left(40{ }^{\circ} \mathrm{C} / \mathrm{min}\right)$ e de $230{ }^{\circ} \mathrm{C}$ por 3 minutos; temperatura de injeção (split), $270{ }^{\circ} \mathrm{C}$; temperatura do FID, $280{ }^{\circ} \mathrm{C}$; volume de injeção, 0,2 mcL; gás hélio de arraste com fluxo de 1,6 mL / min. Os resultados foram expressos em \% do conteúdo total dos ácidos graxos.

\subsubsection{Análise das costelas}

As três últimas costelas aéreas dos animais abatidos foram analisadas com o objetivo de conhecer a análise química da carne, ossos e gordura dos animais. As costelas foram dissecadas separando-se e pesando-se ossos, carne e gordura. Posteriormente os três itens foram reunidos novamente, liofilizados e foram realizadas as seguintes análises químicas: matéria seca $60^{\circ} \mathrm{C}$, matéria seca $100{ }^{\circ} \mathrm{C}$, matéria mineral, extrato etéreo e proteína bruta.

\subsection{Delineamento experimental}

Nos dois experimentos realizados, os animais foram distribuídos nos tratamentos de acordo com o peso, idade e sexo, utilizando-se o delineamento experimental em blocos casualizados.

Os dados foram analisados seguindo os procedimentos do SAS (SAS, 1986), de acordo com modelo envolvendo os efeitos de blocos e tratamentos. Os efeitos de tratamento foram decompostos em linear, quadrático e cúbico para verificar a resposta. 


\section{RESULTADOS E DISCUSSÃO}

\subsection{Experimento - I}

Na Tabela 5 são apresentados os resultados das variáveis ganho diário de peso e consumo diário de ração, referentes à manutenção de catetos durante a fase inicial de reprodução testando diferentes níveis de inclusão da amêndoa de babaçu integral nas rações, enquanto que os dados originais encontram-se nos apêndices 1 e 2 .

Tabela 5 - Médias de ganho diário de peso (GDP) e consumo diário de ração (CDR) de catetos na fase inicial de reprodução

\begin{tabular}{cccccc}
\hline Variáveis & \multicolumn{5}{c}{ Níveis de inclusão de babaçu integral na ração, \% } \\
\hline & 0 & 25 & 50 & 100 & EM $^{\mathrm{b}}$ \\
GDP,g & 0,0070 & 0,0123 & 0,0006 & 0,0086 & 0,009 \\
CDR, g & 326,25 & 334,08 & 263,73 & 189,22 & 34,45 \\
\hline
\end{tabular}

${ }^{a}$ Efeito linear da amêndoa de babaçu integral no CD $(P=0,01)$

${ }^{\mathrm{b}}$ Erro da média

O GDP dos animais que receberam níveis crescentes da amêndoa de babaçu integral apresentou valores baixos, isto ocorreu porque os animais testados estavam em período de reprodução onde ocorre redução do crescimento, entretanto, observa-se uma ligeira tendência em melhorar no nível de inclusão de $25 \%$ e logo a piorar conforme a elevação do nível de babaçu integral nas rações (Tabela 5).

O consumo diário dos catetos neste experimento também aumentou ao nível de inclusão de $25 \%$ de babaçu integral e em seguida diminuiu com efeito linear 
$\left(P=0,01 ;\right.$ CONSUMO= 344,18 $\left.-1,5023 X ; R^{2}=0,6479\right)$ a medida que a proporção de babaçu integral aumentou (Figura 6).

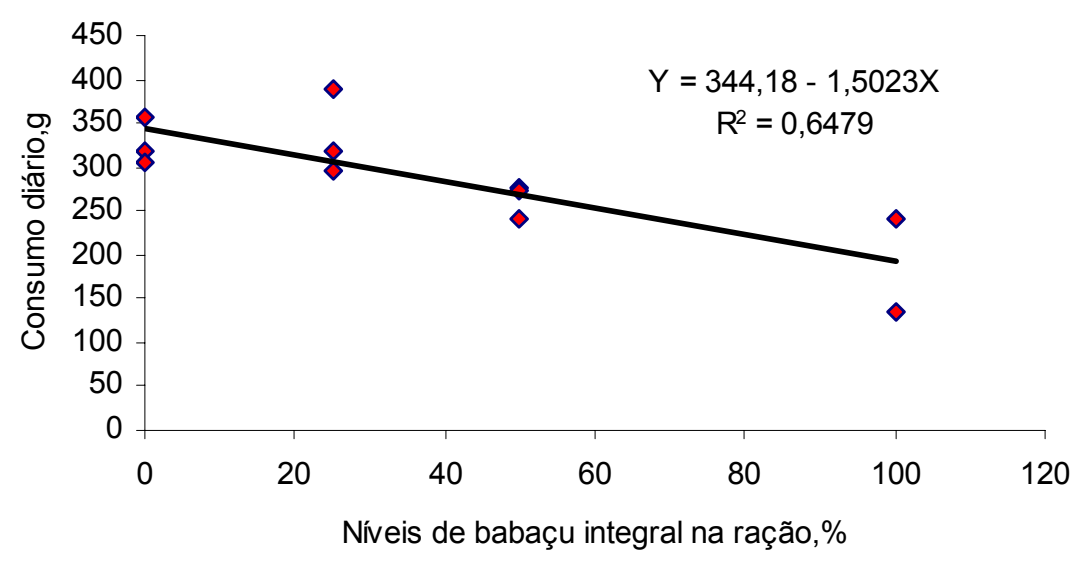

Figura 6. Efeito dos níveis de inclusão de babaçu integral na ração sobre o consumo diário de catetos em fase inicial de reprodução.

Uma vez que obteve-se um efeito depressivo no consumo diário de ração, pode-se sugerir, que o baixo consumo nos níveis de inclusão acima de $25 \%$ da amêndoa de babaçu integral na ração pode ter sido conseqüência do alto teor de óleo existente na amêndoa integral, que pode ter interferido na motilidade ao nível de estômago, já que os animais possuem estômago dividido em compartimentos. Baseando-se em dados de animais ruminantes, o excesso de óleo na dieta, principalmente óleos vegetais, interfere na digestão, diminuem a digestibilidade da fibra (MERCHEN et al., 1997).

Neste experimento foram realizadas análises para pesquisar a presença de taninos no babaçu integral e as mesmas foram negativas. Não foram encontrados dados de literatura sobre efeitos antinutricionais do babaçu mas é um fato que não 
se pode descartar, tanto pela possível interferência de absorção de algum nutriente ou também pela diminuição da palatabilidade da ração.

De acordo com os resultados obtidos sugere-se, que até o nível de $25 \%$ de inclusão de babaçu integral os animais em fase inicial de reprodução conseguem obter desempenho satisfatório, recomenda-se então esta substituição, levando-se em conta que o babaçu integral é uma espécie facilmente encontrada na região Amazônica, tornando-se uma fonte energética economicamente mais barata que o milho.

\subsection{Experimento - II}

$\mathrm{Na}$ Tabela 6 são apresentados os resultados das variáveis ganho diário de peso e consumo diário de ração, referentes à fase de terminação de catetos testando diferentes níveis de inclusão da torta de babaçu nas rações, enquanto que os dados originais encontram-se nos apêndices 3 e 4 .

Tabela 6 - Médias de ganho diário de peso (GDP) e consumo diário de ração (CDR) de catetos na fase de terminação

\begin{tabular}{cccccc}
\hline Variáveis & \multicolumn{5}{c}{ Níveis de inclusão de torta de babaçu na ração, \% } \\
\hline & 0 & 20 & 40 & 60 & EM $^{\text {a }}$ \\
GDP,g & 32,66 & 38,00 & 44,66 & 37,00 & 4,61 \\
CDR, g & 355,53 & 359,06 & 356,06 & 362,16 & 11,40 \\
\hline
\end{tabular}

arro da média

Neste experimento não foram observados efeitos significativos $(P>0,05)$ dos níveis de torta de babaçu sobre o ganho diário de peso e consumo diário. Mesmo assim, observa-se que o ganho diário de peso no nível de inclusão de $40 \%$ de torta de babaçu apresenta um aumento de $36,74 \%$ em relação à ração basal, quanto ao 
consumo diário de ração no mesmo nível, observa-se valores semelhantes ao da ração basal.

A inclusão de $40 \%$ de torta de babaçu em substituição ao milho propiciou melhor desempenho de catetos na fase de terminação, demonstrando o valor nutritivo deste subproduto e a possibilidade de sua utilização nas dietas. O uso de alimentos alternativos como a torta de babaçu nas criações de catetos é de grande importância, pois este subproduto apresenta custo reduzido quando comparado ao milho. A formulação de dietas com substituição de $40 \%$ do milho por torta de babaçu, representa uma economia importante e um incentivo para a criação de catetos em cativeiro.

\subsection{Avaliação da carcaça}

Nas Tabelas 7, 8 , 9 e 10 são apresentados os resultados das variáveis de avaliação da carcaça, referentes aos catetos abatidos do experimento - II onde testaram-se diferentes níveis de inclusão da torta de babaçu nas rações, enquanto que os dados originais encontram-se nos apêndices 5, 6, 7 e 8.

Não foram observados efeitos significativos $(P>0,05)$ dos níveis de torta de babaçu para as variáveis peso vivo, peso em jejum, carcaça quente, carcaça fria, comprimento, sangue, couro, patas traseiras e patas dianteiras conforme mostra a Tabela 7 e os dados originais são encontrados no apêndice 5.

Albuquerque (1993) avaliando a carcaça de capivaras ( $H$. hydrochaeris hydrochaeris) machos, fêmeas e machos castrados abatidas após a fase de terminação, também não encontrou efeitos significativos $(P>0,05)$ para os 
componentes da carcaça embora tenha encontrado uma tendência para carcaças de machos inteiros mais compridas.

Silva et al. (2002) estudaram o efeito de diferentes níveis de proteína bruta na ração de catetos abatidos após a fase de terminação em suas carcaças. Os efeitos também não foram significativos para os parâmetros de carcaça estudados. As médias de comprimento da carcaça foram entre 55,25 a 57,63 cm, valores superiores aos encontrados neste experimento, sendo que os autores não citam a idade dos animais estudados, mas acredita-se que possuíam idade mais avançada devido a diferença de comprimento encontradas.

Tabela 7 - Médias de componentes da carcaça de catetos abatidos após a fase de terminação

\begin{tabular}{cccccc}
\hline Variáveis & \multicolumn{5}{c}{ Níveis de inclusão de torta de babaçu na ração, \% } \\
\hline & 0 & 20 & 40 & 60 & EM $^{\text {a }}$ \\
Peso Vivo, g & 16533,3 & 15633,3 & 16600,0 & 16233,3 & 834,83 \\
Peso Jejum, g & 16466,6 & 15700,0 & 16400,0 & 16000,0 & 746,84 \\
Carcaça Quente,g & 9233,3 & 8266,6 & 9500,0 & 9500,0 & 407,45 \\
Carcaça Fria,g & 9141,0 & 8184,0 & 9405,0 & 9405,0 & 403,37 \\
Comprimento,cm & 22,6 & 21,3 & 20,6 & 20,6 & 0,79 \\
Sangue, g & 148,3 & 211,6 & 216,6 & 203,6 & 26,96 \\
Couro, g & 2088,3 & 1891,6 & 1998,3 & 1980,0 & 103,50 \\
Patas Traseiras, g & 123,3 & 121,6 & 130,0 & 116,6 & 4,68 \\
Patas Dianteiras, g & 121,6 & 121,6 & 120,0 & 120,0 & 2,67 \\
\hline Erro da média & & & & &
\end{tabular}

Neste experimento não foram observados efeitos significativos $(P>0,05)$ dos níveis de torta de babaçu para as variáveis RCQ, RCF (Tabela 8) e costelas, pernil, paleta e \% de pernil em relação à meia carcaça esquerda fria (Tabela 9) dados originais apêndices 7 e 8 . 
Tabela 8 - Médias de rendimento de carcaça de catetos abatidos após a fase de terminação

\begin{tabular}{|c|c|c|c|c|c|}
\hline \multirow[t]{2}{*}{ Variáveis } & \multicolumn{5}{|c|}{ Níveis de inclusão da torta de babaçu na ração, \% } \\
\hline & 0 & 20 & 40 & 60 & $E M^{a}$ \\
\hline $\mathrm{RCQ}^{1}, \%$ & 56,09 & 53,17 & 57,82 & 59,43 & 2,62 \\
\hline $\mathrm{RCF}^{2}, \%$ & 55,53 & 52,64 & 57,24 & 58,84 & 2,59 \\
\hline
\end{tabular}

Tabela 9 - Médias de cortes comerciais retirados da meia carcaça esquerda fria de catetos abatidos após a fase de terminação

\begin{tabular}{|c|c|c|c|c|c|}
\hline \multirow[t]{2}{*}{ Variáveis } & \multicolumn{5}{|c|}{ Níveis de inclusão da torta de babaçu na ração, \% } \\
\hline & 0 & 20 & 40 & 60 & $\mathrm{EM}^{\mathrm{a}}$ \\
\hline Costelas, $\mathrm{g}$ & 1320,0 & 1146,6 & 1146,6 & 1413,3 & 186,59 \\
\hline Pernil, g & 1428,3 & 1420,0 & 1468,3 & 1555,0 & 80,16 \\
\hline Paleta, $g$ & 966,6 & 953,3 & 943,3 & 1028,3 & 67,65 \\
\hline$\%$ Pernil $^{1}$ & 30,6 & 32,4 & 35,3 & 37,2 & 3,40 \\
\hline
\end{tabular}

${ }^{a}$ Erro da média

${ }^{1} \%$ do pernil em relação a meia carcaça esquerda fria

Houve uma tendência para os rendimentos de carcaça quente e fria serem superiores em relação a ração basal de 5,95\% no tratamento com $60 \%$ de inclusão de torta de babaçu, encontrando valores também superiores em relação a ração basal de 3,08\% no nível de inclusão de $40 \%$ de torta de babaçu (Tabela 8 ).

As médias de cortes comerciais encontradas também apresentaram uma tendência a serem superiores ao nível de inclusão de $60 \%$ de torta de babaçu na ração, sendo que houve um aumento em relação a ração de basal de $7,06 \%$ para costelas, $8,87 \%$ para pernil, $6,38 \%$ para paleta e $21,56 \%$ para porcentagem de pernil 
em relação a meia carcaça esquerda fria. Ao nível de inclusão de $40 \%$ de torta de babaçu na ração o aumento foi de $2,80 \%$ para pernil e de $15,35 \%$ para porcentagem de pernil em relação a meia carcaça esquerda fria .

Silva et al. (2002), estudando o efeito de diferentes níveis de inclusão de proteína bruta na ração, na carcaça e carne de catetos abatidos após a fase de terminação, também não encontraram efeitos significativos $(P>-0,05)$ para os parâmetros de carcaça estudados. As médias de rendimento de carcaça ficaram entre 56,88 a $59,47 \%$, valores semelhantes aos deste experimento. A porcentagem de pernil em relação a carcaça ficou entre 35,03 a 38,19, valores ligeiramente superiores ao deste experimento.

Bressan et al. (2002), estudaram a carcaça de capivaras com peso vivo médio de $63,8 \mathrm{~kg}$ encontrando $\mathrm{RCQ}$ entre 46,47 a 53,20 e a porcentagem de pernil em relação à meia carcaça entre 32,3 a $36,9 \%$, valores inferiores de rendimento de carcaça e semelhantes de porcentagem de pernil dos encontrados neste experimento.

Schwarz et al. (1993), estudando os efeitos da somatotropina exógena no desempenho e características de carcaça de bovinos, encontrou médias de rendimento de carcaça entre 57,7 a 58,4 , já Holzer et al. (1999), estudando os efeitos de dois tipos de somatotropina no desempenho, concentração de aminoácidos e ácidos graxos encontrou médias de rendimento de carcaça entre 55,39 a 57,44 .

Comparando-se o rendimento de carcaça de catetos com os dados acima de bovinos, nota-se que os catetos conseguem alcançar valores superiores de rendimento de carcaça. 
Não foram observados efeitos significativos $(P>0,05)$ dos níveis de torta de babaçu para as variáveis estômago, coração, baço, rins e intestino conforme mostra a Tabela 10 e os dados originais são encontrados no apêndice 6.

O fígado e o pulmão dos catetos neste experimento aumentaram de porcentagem quando o nível de inclusão da torta de babaçu aumentou de $0 \%$ para $20 \%$ e depois diminuiu à medida que os níveis de inclusão da torta aumentavam conforme mostra as Figuras 7 e 8, apresentando um efeito quadrático para o fígado $\left(P=0,04 ;\right.$ FÍGADO $=2,1163+0,0365 X-0,0006 X^{2} ; R^{2}=0,4036$, com ponto máximo no nível $30,41 \%)$ e para o pulmão $(P=0,01 ; P U L M A ̃ O=1,3696+0,0269 X-0,0005$ $X^{2 ;} R^{2}=0,4736$, com ponto máximo no nível $26,90 \%$ ), dados originais apêndice 6 .

Tabela 10 - Médias da porcentagem de órgãos e glândulas em relação a carcaça quente de catetos abatidos após a fase de terminação

\begin{tabular}{|c|c|c|c|c|c|}
\hline \multirow[t]{2}{*}{ Variáveis } & \multicolumn{5}{|c|}{ Níveis de inclusão da torta de babaçu na ração, \% } \\
\hline & 0 & 20 & 40 & 60 & $\mathrm{EM}^{\mathrm{b}}$ \\
\hline Estômago,\% & 5,03 & 4,73 & 5,19 & 3,97 & 0,65 \\
\hline Coração, \% & 0,68 & 0,75 & 0,69 & 0,56 & 0,08 \\
\hline Pulmão,\% a1 & 1,32 & 1,85 & 1,49 & 1,21 & 0,11 \\
\hline Fígado, \% ${ }^{\text {a2 }}$ & 2,07 & 2,72 & 2,49 & 2,17 & 0,19 \\
\hline Baço, \% & 1,09 & 0,77 & 0,69 & 0,53 & 0,24 \\
\hline Rins, \% & 0,50 & 0,61 & 0,62 & 0,60 & 0,07 \\
\hline Intestino,\% & 5,88 & 8,24 & 7,29 & 6,51 & 0,93 \\
\hline Total, \% & 16,59 & 19,69 & 18,26 & 15,25 & 1,73 \\
\hline
\end{tabular}

Fisiologicamente podemos relacionar o tamanho do fígado com a proporção de gordura na dieta, sabe-se que é normal o acúmulo de gordura no fígado como uma forma de defesa do organismo para evitar o aumento das gorduras no sangue 
ou estocar o excesso de energia causado por dieta inadequada, porém neste caso à medida que aumentou-se a proporção de torta de babaçu na ração houve uma diminuição do tamanho deste órgão.

A torta de babaçu tem um teor de energia mais elevado que o milho (EE + FB Tabela 3), mas não foram encontrados na literatura dados sobre a digestibilidade da torta de babaçu, provavelmente neste experimento a torta teve uma digestibilidade inferior em relação ao milho, ou seja, a medida que se aumentou o nível de torta na ração houve um menor aproveitamento de energia da ração.

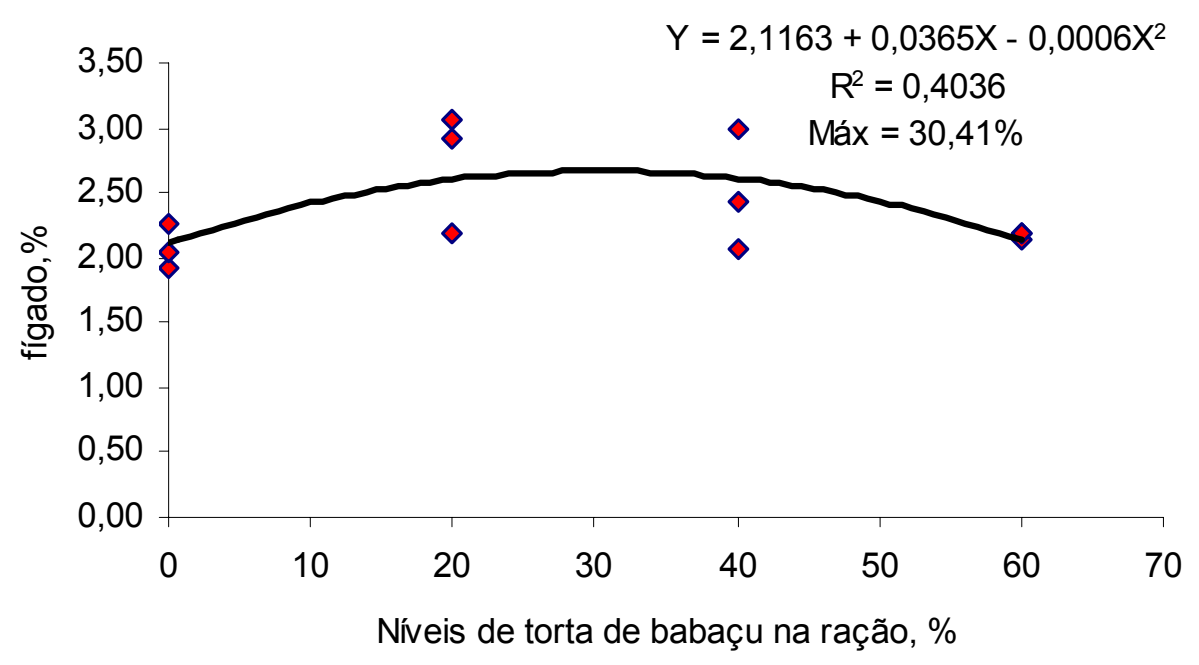

Figura 7. Efeito dos níveis de inclusão de torta de babaçu na ração sobre a porcentagem do fígado em relação a carcaça de catetos em fase de terminação. 


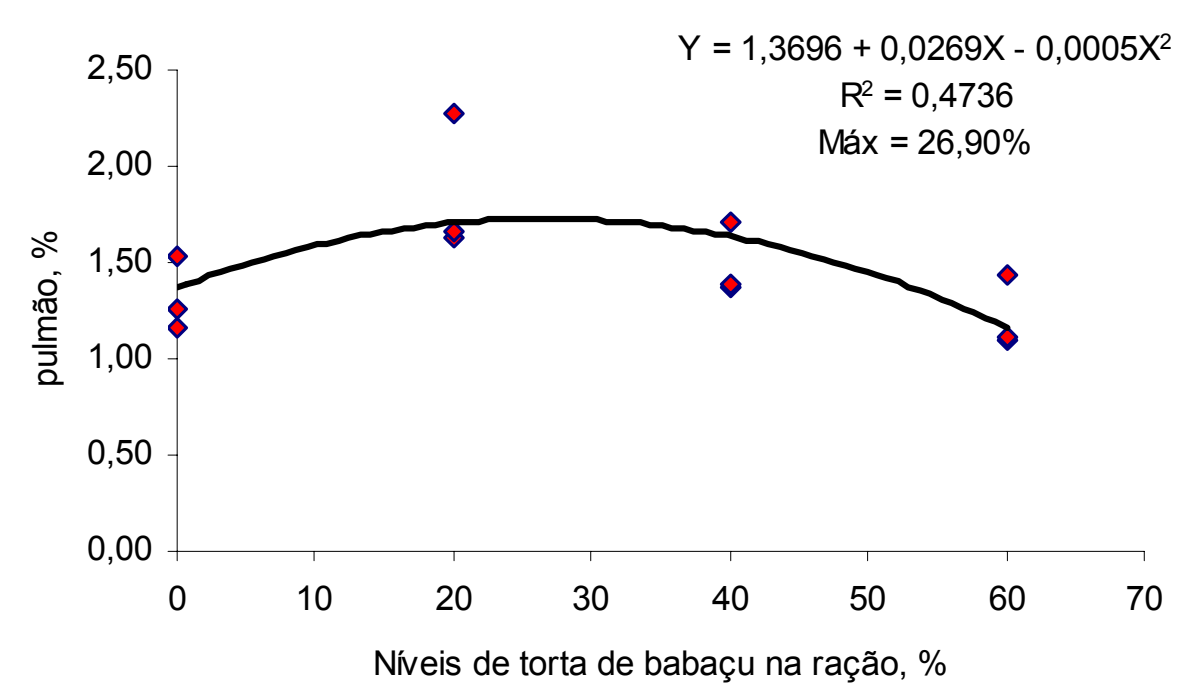

Figura 8. Efeito dos níveis de inclusão de torta de babaçu na ração sobre a porcentagem do pulmão em relação a carcaça de catetos em fase de terminação.

Quanto ao pulmão considerando que as condições de ambiente dos animais experimentais eram semelhantes (instalações, temperatura, umidade, altitude), não encontrando na literatura dados de alteração do peso de pulmão em situações semelhantes, e não podendo-se afirmar que este efeito esteja diretamente relacionado com uma possível variação na energia das dietas, pois não se encontram bases científicas para tal afirmação, supõe-se que provavelmente alguma substância presente na torta de babaçu interferiu nesta variável, sendo necessários estudos futuros afim de investigar este efeito.

\subsection{Análise da carne}

Na Tabela 11 são apresentados os resultados das variáveis de características da carne, referentes aos catetos abatidos do experimento - II onde testaram-se diferentes níveis de inclusão da torta de babaçu nas rações, sendo que os dados originais encontram-se no apêndice 11. 
Não foram observados efeitos significativos $(P>0,05)$ dos níveis de torta de babaçu para as variáveis PPC, FC, pH e CRA. Não foram encontrados na literatura experimentos testando diferentes dietas em catetos com avaliação da carne, mas Bressan et al. (2004) avaliando a carne do músculo Longissimus Dorsi (LD) de capivaras quanto aos fatores sexo e peso de abate também não encontraram efeito entre PPC, FC e CRA.

Os valores da PPC encontrados no pernil de catetos deste experimento variaram entre 15,07 a 22,06\%. Analisando o músculo LD de capivaras Bressan et al. (2004) encontraram PPC entre 31,28 a 33,60\%, já em bovinos adultos, Lesiów; Ockerman (1998) encontraram no mesmo músculo valores entre 38,23 a 40,48. Em ovinos abatidos com peso entre 15 e 45 kg, Souza (2001) descreveu valores entre 35,4 a $38,9 \%$, Prado (2000) também em ovinos abatidos com 15 a $45 \mathrm{~kg}$ de peso vivo, citou valores de 27,6 a 29,1\%. Em músculos LD de suínos Silveira (1997) citou valores de 27,17 a 36,62\% e Renaudeau et al. (2005) encontraram valores de 30,2 e $33,1 \%$ para o mesmo músculo em suínos das raças Crioula e Large White respectivamente. Os valores deste experimento quando comparados com dados de outras espécies na literatura revelam a PPC em catetos mostrou valores abaixo dos relatados.

Neste experimento os valores de FC encontrados variaram entre 3,4 a 5,32 kgf / g. Bressan et al. (2004) encontraram em músculos LD de capivaras valores de FC entre 4,94 a 5,50 kgf / g, Saldanha (2000) encontrou valores de FC entre 4,55 e 4,68 kgf / g em paleta e pernil de capivaras respectivamente. Em bovinos, Mooney et al. (1998) avaliando o músculo LD encontraram médias de FC de 3,85 kgf / g para bovinos alimentados com dieta concentrada e 4,78 kgf / g para bovinos alimentados com forragem. Em ovinos, Prado (2000) encontrou médias entre 2,3 a 2,8 kgf / g e 
Souza (2001) relatou valores entre 5,92 s 13,20 kgf / g. Em ovinos amostras com FC inferior a $11 \mathrm{kgf} / \mathrm{g}$ foi considerada macia (BICKERSTAFFE et al., 1997). Segundo Arima (2006), os efeitos que fazem a maciez ser diferente entre os músculos são: 1) o efeito do complexo actomiosina, 2) o efeito de base e o efeito da densidade ou o efeito de lubrificação. O efeito da actomiosina pode ser observado ou medido pelos seguintes parâmetros: comprimento do sarcômero, diâmetro da fibra muscular e fragmentação do sarcômero. O efeito de base pode ser observado ou medido pelos parâmetros: concentração das proteínas do estroma, tamanho das fibrilas de elastina e solubilidade do colágeno. A densidade ou efeito de lubrificação pode ser expresso na quantidade e distribuição da marmorização. Considerando os limites propostos para ovinos, os valores de FC em pernil de catetos podem ser classificados como macios.

Tabela 11 - Médias de características da carne de pernil de catetos abatidos após a fase de terminação

\begin{tabular}{cccccc}
\hline Variáveis & \multicolumn{5}{c}{ Níveis de inclusão da torta de babaçu na ração, \% } \\
\hline \multicolumn{7}{c}{0} & 20 & 40 & 60 & $\mathrm{EM}^{\mathrm{a}}$ \\
$\mathrm{PPC}^{1}, \%$ & 15,07 & 22,06 & 18,79 & 18,29 & 2,04 \\
$\mathrm{FC}^{2} ., \mathrm{kgf} / \mathrm{g}$ & 5,32 & 3,40 & 4,40 & 4,39 & 1,33 \\
$\mathrm{pH}$ & 6,20 & 6,33 & 6,29 & 6,22 & 0,14 \\
$\mathrm{CRA}^{3}, \%$ & 60,70 & 63,06 & 59,99 & 61,38 & 0,97 \\
\hline a Erro da média & & & & \\
${ }^{1}$ Perdas de peso por cozimento \\
2 Força de cisalhamento \\
${ }^{3}$ Capacidade de retenção de água
\end{tabular}

Quanto a CRA os valores encontrados neste experimento variaram entre 59,99 a 63,06. Segundo Forrest et al. (1979), a CRA é associada com a integridade 
e a quantidade das proteínas no post mortem $(p m)$. Bressan et al. (2004) encontraram valores de CRA em capivaras entre 0,45 a 0,49. Em suínos Silveira (1997) citou variações de 0,39 a 0,54.

Os valores de $\mathrm{pH}$ encontrados no pernil de catetos deste experimento variaram entre 6,2 a 6,33 após 24 horas pm. Os resultados das reações bioquímicas pm é o acúmulo de ácido lático responsável pela acidificação do músculo e conseqüente redução do pH. Bressan et al. (2004) analisando o pH no músculo LD em capivaras encontraram valores médios entre 5,99 a 6,04 24 horas pm. Em ovinos, Prado (2000) encontrou em músculos LD 24 horas pm valores de pH de 5,7 a 5,8. Em bovinos, Wahlgren, Devine e Tornberg (1997), descreveram às 24 horas pm valores de $\mathrm{pH}$ de 5,6.

Outro fator a se considerar é a cor do músculo, as fibras vermelhas contém maior teor de mioglobina que fibras brancas Em fibras vermelhas o estoque de oxigênio na mioglobina está associado a alta proporção de enzimas envolvidas no metabolismo oxidativo e a baixos níveis de enzimas glicolíticas. O processo oxidativo pode estar associado a maior utilização do músculo (mais exercitado), o que também eleva o pH ( HEDRICK et al., 1975).

Comparando os dados encontrados em animais silvestres com os de ovinos e bovinos, o esperado seria um maior descenso de $\mathrm{pH}$ a partir de 5 horas após o abate. Segundo Forrest et al. (1979), o descenso do pH está associado com as reservas de glicogênio no pré-abate e baixas reservas deste são responsáveis por uma baixa extensão da glicólise, instalação superficial do rigor e elevado pH final. Segundo Bressan et al. (2004), em animais silvestres que não estão adaptados a manejos em baias possivelmente não ocorra esta reposição do glicogênio muscular. 
Neste experimento o estresse pré-abate dos catetos foi intenso mesmo tomando todos os cuidados para minimizar os efeitos estressantes de mais de 2 horas de transporte. Além disso, pelo não conhecimento de métodos ideais de abate para esta espécie, os animais não conseguiram ser insensibilizados rapidamente intensificando o estresse, acredita-se que estes fatores tenham caracterizado um elevado pH final. Segundo Oda et al. (2004a), certamente houve um gasto das reservas de glicogênio muscular no pré-abate desencadeando carnes menos ácidas às 24 horas $p m$.

Na Tabela 12 são apresentados os resultados do perfil de ácidos graxos (AG) da carne de pernil, referentes aos catetos abatidos do experimento - II onde se testou diferentes níveis de inclusão da torta de babaçu nas rações.

Os AG encontrados em maior proporção no pernil de catetos foram o C16:0 , o $\mathrm{C} 18: 1$ cis e o $\mathrm{C} 18: 2$ cis . A média do total de AG insaturados foi entre 51,65 a 57,83 , superior ao de saturados que foi entre 42,17 a 48,35. (Tabela 12).

Freire et al. (2000) estudaram AG na carne de pernil de catetos machos inteiros, machos castrados e fêmeas, encontrando C14:0 (1,08 a 1,37\%), C16:0 (21,58 a $24 \%)$, C18:0 (10,59 a 10,77\%) valores inferiores aos deste experimento, C16:1(2,7 a 4,1\%), C18:1 (28,37 a 37,77\%), valores ligeiramente superiores aos deste experimento e C18:2 (13,86 a 22,33\%), C18:3 (0,26 a 0,67\%), valores ligeiramente inferiores aos deste experimento.

A relação AGI/AGS encontrada apresentou uma média de 1,23, valor ligeiramente inferior ao de Freire et al. (2000), que encontraram uma média de 1,46. Analisando-se os dados encontrados, nota-se a presença de uma maior proporção de AG insaturados na carne de catetos. 
Tabela 12- Médias das áreas de pico (\%) dos ácidos graxos encontrados na carne de pernil de catetos abatidos após a fase de terminação

\begin{tabular}{|c|c|c|c|c|}
\hline \multirow[t]{2}{*}{ Ácidos graxos, \% } & \multicolumn{4}{|c|}{ Níveis de inclusão da torta de babaçu na ração, \% } \\
\hline & 0 & 20 & 40 & 60 \\
\hline Ac. Láurico C12:0 & 1,07 & 0,95 & 2,17 & 0,87 \\
\hline Ac.Mirístico,C14:0 & 3,90 & 3,38 & 5,36 & 3,12 \\
\hline Ac.Palmítico, C16:0 & 24,88 & 25,95 & 29,60 & 28,98 \\
\hline Ac.Esteárico, C18:0 & 13,51 & 11,89 & 11,22 & 12,77 \\
\hline $\begin{array}{c}\text { Ac.Palmitoléico, } \mathrm{C} 16: 1^{\mathrm{a}} \\
\omega 7\end{array}$ & 1,18 & 1,41 & 1,08 & 1,45 \\
\hline Ac. Oleico, C18: $1^{\mathrm{a}}$ & 28,47 & 28,64 & 23,47 & 24,81 \\
\hline Ac. Oleico, C18: $1^{\mathrm{b}}$ & 0 & 4,58 & 4,20 & 3,80 \\
\hline $\begin{array}{c}\text { Ac. Linoléico, } \mathrm{C} 18: 2^{\mathrm{a}} \\
\omega 6\end{array}$ & 25,40 & 22,46 & 22,24 & 23,25 \\
\hline $\begin{array}{c}\text { Ac.Linolênico, C18: } 3^{a} \\
\omega 3\end{array}$ & 0,98 & 0 & 0,66 & 0,48 \\
\hline $\begin{array}{c}\text { Ac.eicosenóico C20:1 }{ }^{\mathrm{a}} \\
\omega 9\end{array}$ & 0,61 & 0,74 & 0 & 0,47 \\
\hline Total Saturados & 43,36 & 42,17 & 48,35 & 45,74 \\
\hline Total monoinsaturados & 30,26 & 35,37 & 28,75 & 30,53 \\
\hline Total poliinsaturados & 26,38 & 22,46 & 22,9 & 23,73 \\
\hline Relação AGI/AGS & 1,31 & 1,37 & 1,07 & 1,19 \\
\hline
\end{tabular}

ácidos graxos cis

${ }^{\mathrm{b}}$ Ácidos graxos trans

Renaudeau et al. (2005), analisando o músculo LD de suínos da raça Crioula, encontraram a composição de AG saturados de $40 \%$ e AG monoinsaturados de 40,6\% e concentração de C18:2 de 17,3\% e de 18:3 de 0,96\%. Bragagnolo (2001), encontrou em suínos a composição de AG em porcentagem de, 40+-2, 44+-2 e 14+2 para AG saturados, monoinsaturados e poliinsaturados respectivamente. 
mesmo autor encontrou em bovinos médias em porcentagem de $45+-4$, 40+-4 e 7+-4 para AG saturados, monoinsaturados e poliinsaturados, respectivamente.

Oda et al. (2004b), analisando o músculo Semimembranosus de capivaras observaram valores para AG saturados entre $38 \%$ a $41,61 \%$, AG monoinsaturados entre $27,17 \%$ a $30,83 \%$ e AG poliinsaturados entre $26,63 \%$ a $31,68 \%$. Jardim et al. (2003), analisando o músculo Longissimus dorsi em capivaras entre 30 a 40 kg de PV encontraram médias para AGS de $38,26 \%$, AG monoinsaturados de $11,96 \%$ e poliinsaturados de $28,25 \%$.

Comparando-se a carne de catetos com a de capivaras observa-se que aqueles obtiveram maiores valores para AG saturados e monoinsaturados e valores semelhantes para AG poliinsaturados. Entretanto, comparando com as carnes de bovinos, ovinos e suínos nota-se que o pernil de catetos apresentaram maior teor de AG insaturados, principalmente poliinsaturados e menor teor de AG saturados.

Segundo Jardim et al. (2003), considerando-se os aspectos tecnológicos, geralmente quanto maior o grau de insaturação da gordura das carnes, mais rápido ocorre a oxidação desses compostos lipídicos e menor é a vida-de-prateleira da carne. Todavia, com relação aos aspectos de saúde, os AG poliinsaturados ingeridos na dieta humana são responsáveis por uma redução nos níveis séricos de colesterol.

O colesterol é uma substância pertencente ao grupo dos lipídeos, presente predominantemente no reino animal, os ácidos graxos saturados são considerados hipercolesterolêmicos, a incidência da doença cardiovascular tem sido relacionada com os altos níveis de colesterol sanguíneo e para mantê-lo em baixos níveis recomenda-se uma dieta equilibrada, com baixo teor de lipídeos, colesterol e ácidos 
graxos saturados e maior taxa de ácidos graxos monoinsaturados e poliinsaturados. (BRAGAGNOLO, 2001).

A carne de catetos apresentou um teor de AG insaturados (mono e poliinsaturados) superior ao de AG saturados e superior também ao teor de espécies domésticas como os bovinos, ovinos e suínos. Baseando-se na teoria de que os AG poliinsaturados ingeridos na dieta humana são responsáveis por uma redução nos níveis séricos de colesterol, então a ingestão de carne de catetos seria uma alternativa protéica mais saudável que as carnes de bovinos, ovinos e suínos.

O cateto é considerado um animal não ruminante, entretanto possui estômago dividido em compartimentos, acredita-se que consegue transformar a fibra em ácidos graxos voláteis através da presença de microorgarnismos. Sabe-se que em ruminantes, estes microorganismos são capazes de produzir AG trans, principalmente trans-C18:1, causando a biohidrogenação de $A G$ insaturados (MERCHEN et al., 1997, MARTIN; JENKINS, 2002). Acredita-se que a presença de AG trans na carne de catetos (Tabela 10) possa ser explicada por este motivo.

\subsection{Análise das costelas}

Nas Tabelas 13 e 14 são apresentados os resultados das análises das costelas de catetos abatidos do experimento - II onde se testou diferentes níveis de inclusão da torta de babaçu nas rações, enquanto que os dados originais encontram-se nos apêndices 9 e 10.

Os resultados encontrados não podem ser correlacionados com a carcaça dos animais por não existir na literatura um parâmetro de estimativa para catetos. 
Tabela 13 - Médias das proporções de ossos, músculo e gordura de costelas de catetos abatidos após a fase de terminação.

\begin{tabular}{cccccc}
\hline Variáveis, $g$ & \multicolumn{5}{c}{ Níveis de inclusão da torta de babaçu na ração, \% } \\
\hline Ossos & 0 & 20 & 40 & 60 & EM $^{\mathrm{b}}$ \\
Músculo & 8,91 & 9,83 & 9,59 & 10,84 & 0,55 \\
Gordura $^{\mathrm{a}}$ & 57,40 & 59,98 & 50,79 & 67,34 & 7,47 \\
Total & 10,20 & 8,22 & 6,56 & 10,01 & 0,93 \\
\hline
\end{tabular}

afeito quadrático da torta de babaçu na Gordura $(\mathrm{P}=0,02)$

${ }^{\mathrm{b}}$ Erro da média

A gordura de costelas de catetos deste experimento mostrou, um efeito quadrático $\left(P=0,02 ;\right.$ GORDURA $=10,439-0,2148 X+0,0034 X^{2} ; R^{2}=0,2749$, com ponto mínimo no nível $31,58 \%$ ), diminuindo quando se incluiu a torta de babaçu na ração e aumentando no nível de inclusão de $60 \%$ da torta de babaçu na ração, notando-se que a este nível a gordura na costela de catetos se assemelhou a ração basal ( $0 \%$ de torta de babaçu) (Figura 9$)$.

O ponto mínimo indica o nível máximo de diminuição da gordura, sendo que este se aproxima do nível de inclusão de $40 \%$ de torta de babaçu (Figura 9), indicando ser um nível adequado para a obtenção de carcaças mais magras. 


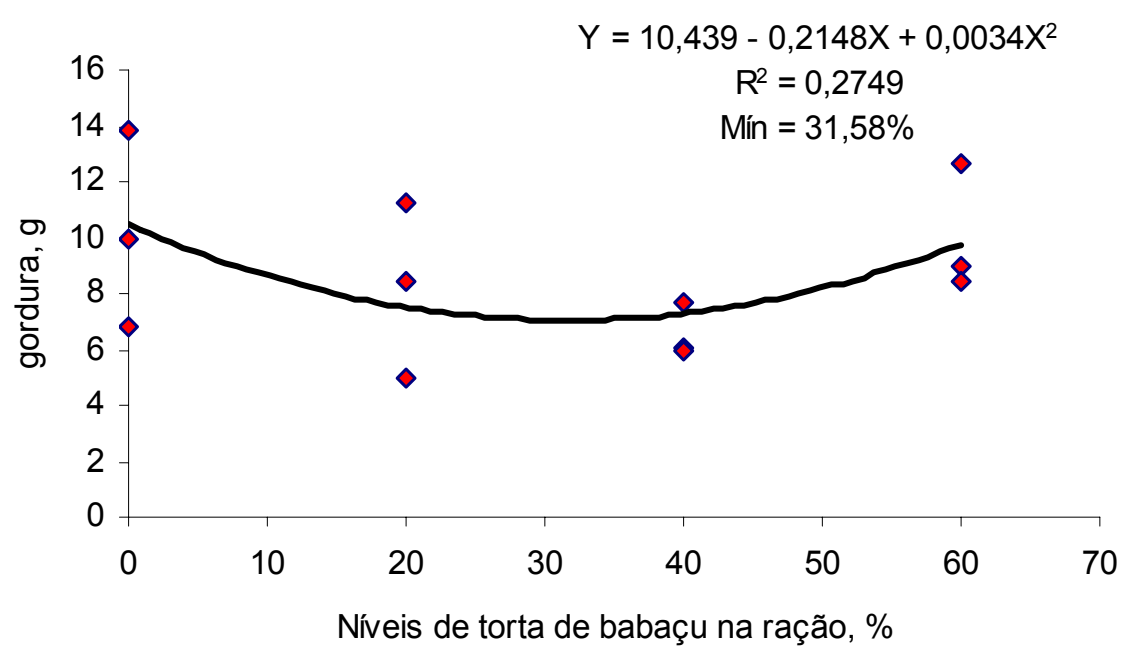

Figura 9. Efeito dos níveis de inclusão de torta de babaçu na ração sobre o peso da gordura de costelas de catetos em fase de terminação.

A matéria mineral da análise bromatológica de costelas dos catetos neste experimento apresentou efeito linear $\left(P=0,02 ; M M=134,46+0,8787 X ; R^{2}=0,3226\right)$ e efeito cúbico $\left(P=0,009 ; M M=145,21-7,451 X+0,3981 X^{2}-0,0044 X^{3} ; R^{2}\right.$ $=0,7928$ ) a medida que a proporção de torta de babaçu aumentava, conforme mostram a Tabela 14 e as Figuras 10 e 11. Sabe-se, que a matéria mineral da torta de babaçu é maior que a do milho (Tabela 3), supõe-se então que houve um acúmulo de minerais disponíveis na dieta porque além disso, a dieta continha suplementos vitamínico e mineral. Baseando-se no fato de que o excesso de minerais na dieta ocasiona uma maior absorção e levando-se em conta que os animais são seletivos em sua alimentação, ou seja, consomem nutrientes de acordo com sua necessidade biológica, acredita-se que houve um desequilíbrio na absorção de minerais. 
Tabela 14 - Médias das análises químicas bromatológicas de costelas de catetos abatidos após a fase de terminação

\begin{tabular}{cccccc}
\hline \multicolumn{5}{c}{ Variáveis } & \multicolumn{5}{c}{ Níveis de inclusão da torta de babaçu na ração, \% } \\
\hline $\begin{array}{ccccc}\mathrm{MS}^{1}, \mathrm{~g} / \mathrm{kg} \mathrm{MF} \\
\mathrm{MM}^{3}, \mathrm{~g} / \mathrm{kg}\end{array}$ & 980,56 & 988,68 & 986,10 & 986,69 & 3,61 \\
$\mathrm{MS}^{1 \mathrm{a}, \mathrm{b}}$ & 145,20 & 120,07 & 201,28 & 176,71 & 12,50 \\
$\mathrm{EE}^{4}, \mathrm{~g} / \mathrm{kg} \mathrm{MS}^{1}$ & 141,89 & 190,40 & 115,51 & 153,10 & 35,39 \\
$\mathrm{~PB}^{5}, \mathrm{~g} / \mathrm{kg} \mathrm{MS}^{1}$ & 603,99 & 584,01 & 638,61 & 662,25 & 39,28 \\
\hline
\end{tabular}

a Efeito linear da torta de babaçu na MM $(P=0,02)$

${ }^{, b}$ Efeito cúbico da torta de babaçu na MM $(P=0,009)$

${ }^{\mathrm{c}}$ Erro da média

${ }^{1}$ Matéria Seca

${ }^{2}$ Matéria Fresca

${ }^{3}$ Matéria Mineral

${ }^{4}$ Extrato Etéreo

${ }^{5}$ Proteína Bruta

Silva et al. (2002), analisaram a carne de catetos em diferentes níveis de proteína bruta na ração encontrando PB entre 19,57 a 21,40\%, EE entre 6,73 a $8,50 \%$, MM entre 0,76 a $1,14 \%$, valores inferiores aos deste experimento, sendo que os autores acima avaliaram somente a carne e não citaram qual foi o músculo estudado.

Gálvez et al. (1999), estudaram o valor nutritivo de carnes de catetos e outras espécies silvestres consumidas na cidade de lquitos - Peru, encontrando para catetos proteína $76,35 \%$, extrato etéreo de $1,49 \%$ e cinzas de $1,27 \%$ valores diferentes aos deste experimento sendo que os autores citam somente que analisaram partes comestíveis não especificando o músculo estudado. 


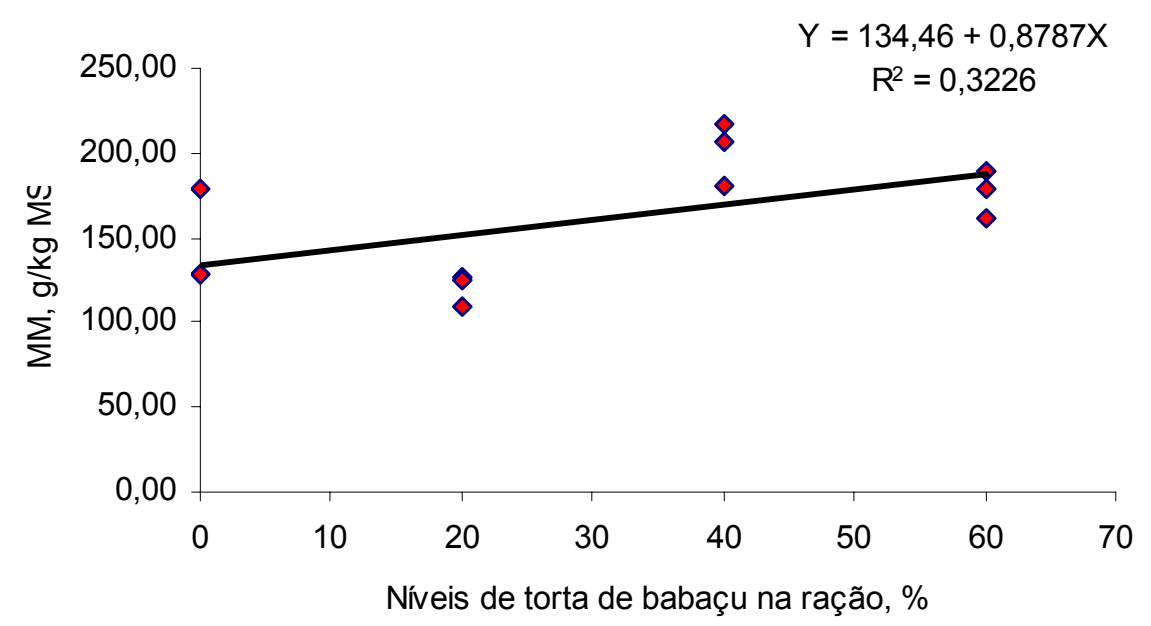

Figura 10. Efeito dos níveis de inclusão de torta de babaçu na ração sobre a proporção de matéria mineral nas costelas de catetos em fase de terminação

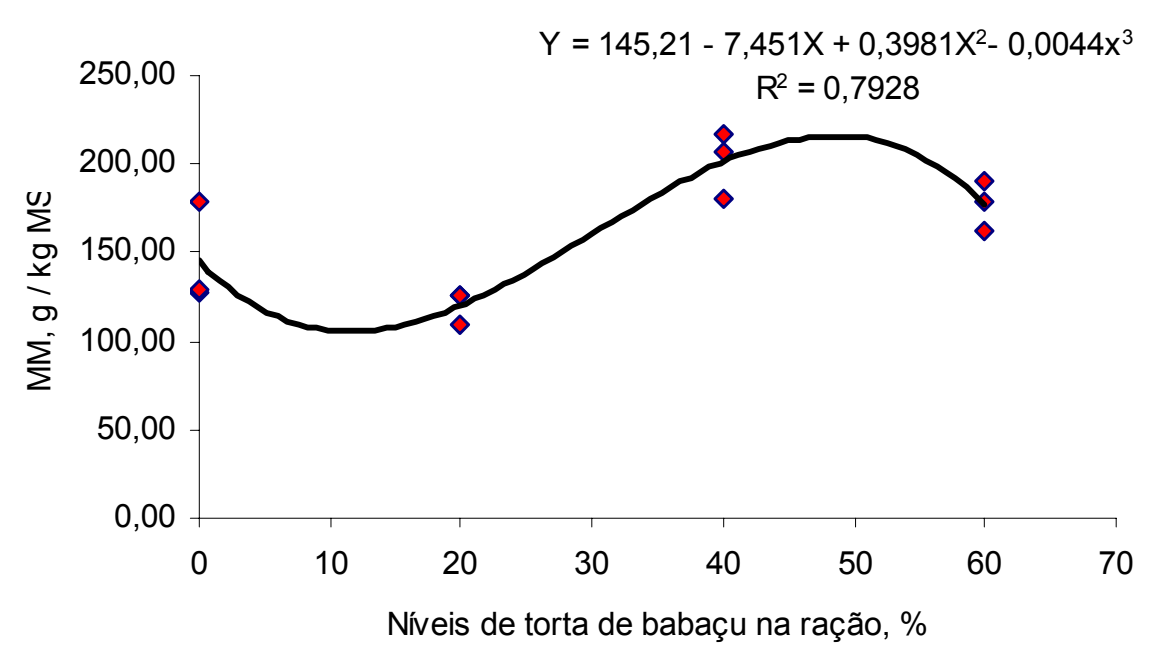

Figura 11. Efeito dos níveis de inclusão de torta de babaçu na ração sobre a proporção de matéria mineral nas costelas de catetos em fase de terminação 


\section{CONCLUSÕES}

a) Sugere-se que o babaçu integral é uma alternativa energética viável até o nível de $25 \%$ em substituição ao milho em rações para catetos em mantença.

b) A torta de babaçu pode substituir o milho como fonte energética até o nível de $40 \%$ em rações para catetos na fase de terminação.

c) A torta de babaçu até o nível de $40 \%$ em substituição ao milho obteve bons resultados de rendimento de carcaça e cortes comerciais de catetos abatidos na fase de terminação.

d) De acordo com os resultados obtidos, a carne de cateto tem perda de peso por cozimento, força de cisalhamento, capacidade de retenção de água e pH satisfatórios quando comparada com dados de bovinos, ovinos e suínos.

e) Baseando-se no teor de AG insaturados, a carne de catetos é uma fonte alternativa excelente de proteínas. 


\section{REFERÊNCIAS}

ALBUQUERQUE, N.I. Ganho de peso na fase final de crescimento e sistematizaçao da avaliação de carcaça de três categorias de capivaras (Hydrochoerus hydrochaeris hydrochaeris I. 1766): machos inteiros, machos castrados e fêmeas. 1993. 65 f. Dissertação (Mestrado) - Escola Superior de Agricultura “Luiz de Queiroz”, Universidade de São Paulo, Piracicaba, 1993.

ALBUQUERQUE, N.I. Alternativas de sistemas de produção de caititu (Tayassu tajacu) para a pequena agricultura na Amazônia. In: BRASIL. Ministério da Ciência e Tecnologia. Projetos de Pesquisa Dirigida (PPDs) - PPG7 / Subprograma de Ciência e Tecnologia. Brasília, 2002. p.107-112.

ALBUQUERQUE, N.I.; HÜHN, S. Avaliação físico-química de espécies vegetais utilizadas na alimentação do caititu. Boletim de Pesquisa. Embrapa Amazônia Oriental, Belém, n.36, p.1-17, 2001.

ALBUQUERQUE, N.I.; GUIMARAES, D.A.; SILVA, J.V.; LE PENDU, Y.; HILMA, L.D. 2004. Nutrition and sanitary characteristics of collared peccary (Tayassu tajacu) for small producers in the Amazon region. In: SYMPOSIUM SUR L'UTILISATION DE LA FAUNE SAUVAGE, 6., 2004, Paris. Resumenes... Paris, 2004a. p.128-129.

ALBUQUERQUE, N.I.; GUIMARAES, D.A.; LE PENDU, Y.; SILVA, J.V. Criação intensiva de caititus (Tayassu tajacu): Experiência na Amazônia Brasileira. In: CONGRESO INTERNACIONAL SOBRE MANEJO DE FAUNA SILVESTRE EM LA AMAZÔNIA Y LATINOAMERICA, 6., 2004, Iquitos. Resumos... Iquitos: WCS, DICE, UNAP, 2004b. p.21-22.

ALTRICHTER, M.; SÁENZ, J.C.; CARRILLO, E.; FULLER, T.K. Dieta estacional del Tayassu pecari (Artiodactyla: Tayassuidae) en el Parque Nacional Corcovado, Costa Rica. Revista de Biología Tropical, San José, v.48, n.2-3, p.689-702, 2000. 
ALVARADO HUALLANCO, M.B. Aplicação de um sistema de classificação de carcaças e cortes e efeito pós abate da qualidade de cortes de frango criados no sistema alternativo. 2004. Dissertação (Mestrado) - Escola Superior de Agricultura Luiz de Queiroz, Piracicaba, 2004.

ASSOCIAÇÃO BRASILEIRA DE CRIADORES DE SUÍNOS. Método brasileiro de classificação de carcaça. Estrela: ABCS, 1973. 17p.

ARIMA, H.K. Maturação de carnes. In: CONTRERAS, C.C. Qualidade de carnes. São Paulo: Ed. Varela, 2006. cap.8, p.155-156. No prelo.

BABAÇU. Disponível em: <http://www.bibvirt.futuro.usp.br/especiais/frutasnobrasil/ babacu.htmL>. Acesso em: 09 dez. 2005.

BARBELLA, S.L. Determinación del ciclo estral en el báquiro de collar (Tayassu tajacu). Revista de la Faculta de Agronomia, Maracay, v. 19, p.167-174,1993.

BICKERSTAFFE, R.; LE COUTER, C.E.; MORTON, J.D. Consistency of tenderness in New Zealand retail meat. In: INTERNACIONAL CONGRESS OF MEAT SCIENCE AND TECHNOLOGY, 43., 1997, Auckland. Anais... Auckland: ICOMST, 1997.

BLIGH, E. G.; DYER, W. J. A rapid method of total lipid extraction and purification. Canadian Journal of Biochemistry and Physiology, Ottawa, v.37, n.8, p.911-917, 1959.

BODMER, R.E. Responses of ungulates to seasonal inundations in the Peruvian Amazon floodplain. Journal of Tropical Ecology, Cambridge, v.6, p.191-201, 1990.

BODMER, R.E. Strategies of seed dispersal and seed predation in Amazonian ungulates. Biotropica, Washington, v.23, p.255-261, 1991.

BODMER, R.E. The economics of sustainable harvests of mammals in the Peruvian Amazon. In: MANEJO DA VIDA SILVESTRE PARA A CONSERVAÇÃO NA AMÉRICA LATINA, 1992, Belém. Resumos... Belém, 1992. p.50-52. 
BODMER, R.E. Integrating hunting and protected areas in the Amazon. In: DUNSTONE, N.; ENTWISTLE, A. (Ed.). Future priorities for the conservation of mammals: has the panda had its day? Cambridge: Cambridge University Press, 2000.

BODMER, R.E.; BENDAYAN ACOSTA, N.Y.; IBAÑEZ, L.M.; FANG, T.G. Manejo de ungulados en la Amazônia peruana: analises de su caza y comercializacion. Boletim de Lima, Lima, v.70, p.49-56, 1990.

BODMER, R.E.; AQUINO, R.; PUERTAS, P.; REYES, C.; FANG, T.Y.; GOTTDENKER, N. Manejo y uso sustentable de pecaríes en la Amazonía peruana. Quito: Secretaría CITES, 1997. 102p. (Ocasional Paper of the IUCN Species Survival Comisión, 18).

BODMER, R.E.; ALLEN, C.M.; PENN, J.W.; AQUINO, R.; REYES, C. Evaluating the Sustainable use of wildlife in the Pacaya-Samiria Natinal Reserve, Peru. America Verdi, n.4a, p.36, 1999.

BONAUDO, T.; LE PENDU, Y.; ALBUQUERQUE, N.I. Caça de animais silvestres na Rodovia Transamazônica. In: SIMPÓSIO INTERNACIONAL DA IUFRO MANEJO INTEGRADO DE FLORESTAS ÚMIDAS NEOTROPICAIS POR INDÚSTRIAS E COMUNIDADES, 2002, Belém. Resumo expandido... Belém: CIFOR, Embrapa Amazônia Oriental, 2002.

BRAGAGNOLO, N. Aspectos comparativos entre carnes segundo a composição de ácidos graxos e teor de colesterol. In: CONFERÊNCIA INTERNACIONAL VIRTUAL SOBRE QUALIDADE DE CARNE SUÍNA, 2., 2001, Concórdia. Concórdia: Embrapa Suínos $\quad$ Aves, 2001. Disponível em: <http://www.conferencia.uncnet.br/pork/programa.html>. Acesso em: 15 de dez. 2005.

BRASIL. Ministério das Relações Exteriores. The State of Maranhão. Disponível em: <http://www.mre.gov.br/ndsg/textos/marest-i.htm>. Acesso em: 14 fev. 2002. 
BRESSAN, M.C.; MIGUEL, G.Z.; FARIA, P.B.; VIEIRA, J.O.; ODA, S.H.I. Rendimento de carcaça e de cortes comerciais de capivaras (Hydrochaeris hydrochaeris L. 1766). Ciência e Agrotecnologia, Lavras, ed. especial, p.15881593, 2002.

BRESSAN, M.C.; JARDIM, N.S.; PEREZ, J.R.O.; THOMAZINI, M.; LEMOS, A.L.S.C.; ODA, S.H.I.; PISA, A.C.C.; VIEIRA, J.O.; FARIA, P.B.; FREITAS, R.T.F. Influência do sexo e faixas de peso ao abate nas características físico-químicas da carne de capivara. Ciência Tecnologia de Alimentos, Campinas, v.24, n.3, p.357362, 2004.

CARL, G.R.; BROWN, R.B. Protozoa in the forestomach of the collared peccary (Tayassu tajacu). Journal of Mammalogy, Baltimore, v.64, n.4, p.709, 1983.

CARL, G.R.; BROWN, R.B. Protein requirement of adult collared peccaries. Journal of Wildlife Management, Menasha, v.49, p.351-355, 1985.

CAVALCANTE FILHO, M.F.; MIGLINO, M.A.; MACHADO, G.V.; BEVILACQUA, E.; NEVES, W.C. Estudo comparativo sobre o suprimento arterial do estômago do queixada ( Tayassu pecari ) e do cateto ( Tayassu tajacu ) ( Linnaeus, 1789). Brazilian Journal of Veterinary Research and Animal Science, São Paulo, v.35, n.1, 1998.

CHRISTIE, W.W. Lipid analysis. Oxford: Pergamon Press, 1982. cap.3, p.25-49: Chromatografic and spectroscopic analysis of lipids. General principles.

COMIZZOLI, P.; PEINIAU, J.; DUTERTRE, C.; PlANQUETTE, P.; AUMAITRE, A. Digestive utilization of concentrated and fibrus diets by two peccary species (Tayassu peccari, Tayassu tajacu) raised in French Guyana. Animal Feed Science Technology, Amsterdam, v.64, n.2-4, p.215-226, 1997.

CONTRERAS, C.C.; CUSTODIO, C.V. Atributos de qualidade em carcaças de frangos: vale a pena avaliar em nível de produção industrial. In: CONFERÊNCIA 
APINCO DE CIÊNCIA E TECNOLOGIA AVÍCOLAS, Campinas, 2002. Anais... Campinas: FACTA, 2002. p.31-45.

EMPRESA BRASILEIRA DE PESQUISA AGROPECUÁRIA. Centro Nacional de Pesquisa de Suínos e Aves. Tabela de composição química e valores energéticos de alimentos para suínos e aves. 3.ed. Concórdia: EMBRAPA, CNPSA, 1991. 97p. (Documentos, 19).

FORREST, J.C.; ABERLE, E.D.; HEDRICK H.B.; JEDGE, M.D.; MERKEL, R.A. Fundamentos de ciência de la carne. Zaragoza: Acribia, 1979. 364p.

FREIRE, K.R.; BESERRA, F.J.; PINHEIRO, M.J.P.; NOGUEIRA, C.M.; CARRARO, F. Efeito do sexo e da castração no perfil de ácidos graxos e teor de colesterol da carne de cateto (Tayassu tajacu). In: CONGRESSO BRASILEIRO DE CIÊNCIA E TECNOLOGIA DE ALIMENTOS, 17., Fortaleza, 2000. Anais... Fortaleza: CBCTA, 2000.

FUCCIO, H.; CARVALHO, E.F.; VARGAS, G. Perfil da caça e dos caçadores no Estado do Acre, Brasil. Revista Aportes Andinos, Quito, n.6, 2003. Disponível em: <http://www.uasb.edu.ec/padh/centro/pdfs6/Heloisa\%20Fuccio.pdf>. Acesso em: 20 mar. 2004.

GÁLVEZ, H.; ARBAIZA, T.; CARCELÉN, F.; LUCAS, O. Comunicaciones: valor nutritivo de lãs carne de sajino (Tayassu tajacu), venado colorado (Mazama americana), majaz (Agouti paca) y motelo (Geochelone denticulata). Revista de Investigaciones Veterinárias del Peru, Lima, v.10, n.1, p.82-86, 1999.

GUIMARÃES, D.A. de A. Algumas características reprodutivas da cutia fêmea Dasyprocta prymnolopha (Wagler, 1831) criada em cativeiro. 1993. 89 f. Dissertação (Mestrado) - Universidade Federal do Pará, Belém, 1993.

GUIMARAES, D.A.; SILVA, J.V.; MAYOR, P.; LE PENDU, Y.; ALBUQUERQUE, N.I.; NOGUEIRA FILHO, S.L.G. Reproductive biology of female collared peccaries (Tayassu tajacu) raised in captivity in Amazon region. In: SYMPOSIUM SUR 
L'UTILISATION DE LA FAUNE SAUVAGE, 6., 2004, Paris. Resumenes... Paris, 2004. p.136-137.

HANIKEL, K. O. Reference methods for the assessment of physical characteristics of meat. Meat Science, Oxon, v.49, n.4, p.447-457, 1998.

HARTMAN, L.; LAGO, R.C. Rapid determination of fatty acid methyl esthers from lipids. Laboratory Practice, London, v.22, n.7, p.475-476, 1973.

HEDRICK, H.B.; ABERLE, E.D.; FORREST, J.C.; JUDGE, M.D.; MERKEL, R.A. Structure and composition of muscle and associated tissues. lowa: Kendall/Hunt Publishing Company, 1975. cap.2, p.11-53: Principles of meat science.

HOLZER, Z.; AHARONI, Y.; BROSH, A.; ORLOV, A.; VEENHUIZEN, J.J.; KASSER, T.R. The effects of long-term administration of recombinant bovine somatotropin (Posilac) and Synovex on performance, plasma hormone and amino acid concentration, and muscle and subcutaneous fat fatty acid composition in HolsteinFriesian bull calves. Journal of Animal Science, Albany, v.77, p.1422-1430, 1999.

ILSE, L.M.; HELLGREN, E.C. Resource partitioning in sympatric populations of collared peccaries and feral hogs in southern Texas. Journal of Mammalogy, Baltimore, v.76, p.784-799, 1995.

JARDIM, N.S.; BRESSAN, M.C.; LEMOS, A.L.S.C.; THOMAZINI, M.; FERREIRA, M.W. Teor lipídico e perfil de ácidos graxos da carne de capivara (Hydrochaeris hydrochaeris). Ciência Agrotécnica, Lavras, v.27, n.3, p.651-657, 2003.

JOHN DEERE DO BRASIL. Babaçu. Disponível em: <http://www.deere.com.br/sulco 12 receita.asp>. Acesso em: 14 fev. 2002.

LANGER, P. Stomach evolution in the artiodactyla. Mammalia, Paris, v.38, n.2, 1974. 
LANGER, P. Adaptational significance of the forestomach of the collared peccary, Dicotyles tajacu (L. 1758) (Mammalia: Artiodactyla). Mammalia, Paris, v.43, n.2, 1979.

LE PENDU, Y.; VENTURIERI, B.; SILVA, P.D.; LESSA, M.; NOGUEIRA, S.S.C. Behavioral characteristics of captive collared peccary (Tayassu tajacu) in the Brazilian Amazon region. In: SYMPOSIUM SUR L'UTILISATION DE LA FAUNE SAUVAGE, 6.; INTERNATIONNAL WILDLIFE RANCHING SYMPOSIUM, 4., 2004, Paris. La faune sauvage: une ressource naturelle; annals... Paris, 2004. p. 147-148.

LESIÓW, T.; OCKERMAN, H.W. Functional and sensory attributes of normal pH values in Sm e Ld of Bull muscles depending on time of cutting and aging. In: INTERNATIONAL CONGRESS OF MEAT SCIENCE AND TECHNOLOGY, 44., 1988, Barcelona. Anais... Barcelona: ICOMST, 1998.

MARTIN, S.A.; JENKINS, T.C. Factors affecting conjugated linoleic acid and transC18:1 fatty acid production by mixed ruminal bacteria, Journal of Animal Science, Albany, v.80, p.3347-3352, 2002.

MERCHEN, N.R.; ELIZALDE, J.C.; DRACKLEY, J.K. Current perspective on assessing site of digestion in ruminants. Journal of Animal Science, Albany, v.75, p.2223-2234, 1997.

MONTGELARD, C.; DUCROCQ, S.; DOUZER, E. What is suiforme (Artiodactyla)? Contribution of cranioskeletal and mitochondrial DNA data. Molecular Phylogenetics and Evolution, San Diego, v.9, n.3, p.528-532, 1998.

MOONEY, M.T.; FRENCH, P.; MOLONEY, A.P.; RIORDAN, E.O.; TROY, D.J. Quality differences between herbage and concentrate -fed beef animals. In: INTERNATIONAL CONGRESS OF MEAT SCIENCE AND TECHNOLOGY, 44., Barcelona, 1998. Anais... Barcelona: ICOMST, 1998.

MORAES, L.F.D. Digestibilidade de nutrientes de rações contendo níveis crescentes de volumosos determinada com catetos (Tayassu tajacu L.) Wetzel, 
1977) e queixadas (Tayassu pecari, Link, 1795). 1992. 97 f. Dissertação (Mestrado) - Escola Superior de Agricultura "Luiz de Queiroz", Universidade de São Paulo, Piracicaba, 1992.

MOURA, A.C.A.; SILVA, E.L.F.; FONTES, S.G.F.; MAIA,M.B.S. Avaliação do efeito de Orbignia phalerata Mart. (babaçu) em modelos experimentais de úlcera. Recife: UFPe, 2002. Disponível em: <http://www.propesq.Ufpe.br/conic97/ccb/RES30064.htmL>. Acesso em: 20 nov. 2003

NAKAMURA, M.; KATOH, K. Influence of thawing method on several properties of rabbit meat. Bulletin of Ishika Prefecture College of Agriculture, v.11, n.1, p.4549, 1985.

NATIONAL RESEARCH COUNCIL - NRC. Microlivestock: Little-known small animals with a promising economic future. Washington: National Academy Press, 1991.

NEAL, B.J. Techniques of trapping and tagging the collared peccary. Journal of Wildlife Management, Menasha, v.21, p.11-16, 1958.

NEPSTAD, D.C.; UHL, C.; SERRÃO, E.A.S. Recuperation of a degraded Amazonian landscape: forest recovery and agricultural restoration. Ambio, Stockholm, v.20, p.248-255, 1991.

NOGUEIRA FILHO, S.L.G. Gerenciamento de Tayassuidae em cativeiro. In: MANEJO DA VIDA SILVESTRE PARA A CONSERVAÇÃO NA AMÉRICA LATINA, 1992, Belém. Resumos... Belém, 1992. p.46-48.

NOGUEIRA FILHO, S.L.G. Criação de cateto e queixada. Viçosa: CPT, 1999. $170 p$.

NOGUEIRA FILHO, S.L.G.; ARGÔLO, G.R.; MENDES, A.; NOGUEIRA, S.S.C. Análise do consumo de carne de animais silvestres no sul da Bahia, Brasil. In: CONGRESO INTERNACIONAL SOBRE MANEJO DE FAUNA SILVESTRE EM LA 
AMAZÔNIA Y LATINOAMERICA, 6., 2004, Iquitos. Resumos... Iquitos: WCS, DICE, UNAP, 2004a. p.97.

NOGUEIRA FILHO, S.L.G.; SANTOS, D.O;; MENDES, A.; NOGUEIRA, S.S.C. A criação de caititus (Tayassu tajacu) como alternativa de diversificação de produção de renda na região cacaueira da Bahia, Brasil. In: CONGRESO INTERNACIONAL SOBRE MANEJO DE FAUNA SILVESTRE EM LA AMAZÔNIA Y LATINOAMERICA, 6., 2004, Iquitos. Resumos.... Iquitos: WCS, DICE, UNAP, 2004b. p.98.

ODA, S.H.I.; BRESSAN, M.C.; MIGUEL, G.Z.; VIEIRA, J.O.; FARIA, P.B.; SAVIAN, T.V.; KABEYA, D.M. Efeito do método de abate e do sexo sobre a qualidade da Carne de capivara (Hydrochaeris hydrochaeris). Ciência e Tecnologia de Alimentos, Campinas, v.24, n.3, p.341-346, 2004a.

ODA, S.H.I.; BRESSAN, M.C.; CARDOSO, M.G.; FREITAS, R.T.F.; MIGUEL, G.Z.; FARIA, P.B.; VIEIRA, J.O.; PISA, A.C.C.; SAVIAN, T.V. Efeitos dos métodos de abate e sexo na composição centesimal, perfil de ácidos graxos e colesterol da carne de capivaras. Ciência e Tecnologia de Alimentos, Campinas, v.24, n.2, p.236-242, 2004b.

OLIVEIRA, R.B.; MELO, J.B. de. O caititu. Santarém: IARA/IBAMA - GOTAZ/GTZ, 1999. (IARA em Quadrinhos, 8).

PACKARD, J.M.; BABBITT, K.J.; FRANCHEK, K.M.; PIERCE, P.M. Sexual competition in captive collared peccaries (Tayassu tajacu). Applied Animal Behaviour Science, Amsterdam, v.29, p.319-326, 1991.

PINO, L.M. Estabilidade oxidativa da carne de frangos alimentados com diferentes fontes lipídicas, armazenada sob congelamento. 2005. Dissertação (Mestrado) - Escola Superior de Agricultura Luiz de Queiroz, Piracicaba, 2005. 60p.

PRADO, O.V. Qualidade de carme de cordeiros Santa Inês e Bergamácia abatidos em diferentes pesos. 2000. 109 f. Dissertação (Mestrado) - Universidade Federal de Lavras, Lavras. 2000. 
RENAUDEAU, D.; HILAIRE, M.; MOUROT, J. A comparison of carcass and meat quality characteristics of Creole and Large White pigs slaughtered at 150 days of age. Animal Research, Les Ulis, v.54, p.43-54, 2005. Disponível em: <http://www.pigtrop.cirad.fr/fr/actualites/article.htm>. Acesso em: 20 dez. 2005.

RHEE, K.S.; ZIPRIN, Y.A.; ORDONEZ, G.; BOHAC, C.E. Fatty acid profiles and lipid oxidation in pork muscles as affected by canola oil in the animal diet and muscle location. Meat Science, Oxon, v.23, p.201-210, 1988.

ROBINSON, J.G.; BODMER, R.E. Towards wildlife management in tropical forests. Journal of Wildlife Management, Menasha, v.63, p.1-13, 1999.

ROSTAGNO, H.S.; ALBINO, L.F.T.; DONZELE, J.L.; GOMES, P.C.; FERREIRA, A.S.; OLIVEIRA, R.F.; LOPES, D.C. Tabelas brasileiras para aves e suínos: composição de alimentos e exigências nutricionais. Viçosa: UFV, 2000. 141p.

SALDANHA, T. Determinação da composição centesimal nos diferentes cortes da carne de capivara (Hydrochoerus hydrochaeris). 2000. 105 f. Dissertação (Mestrado) - Universidade Federal Rural do Rio de Janeiro, Rio de Janeiro. 2000.

SANTOS, D.O.; NOGUEIRA FILHO, S.L.G.; MENDONÇA, S.S.; PIRES, J.V.; SILVA, F.F.; PEREIRA, M.L.A. Digestibilidade aparente "in vivo" de alimentos utilizados na dieta de caititus (Tayassu tajacu). In: REUNIÃO ANUAL DA SOCIEDADE BRASILEIRA DE ZOOTECNIA, 41., 2004, Campo Grande. Resumos... Campo Grande: SBZ, 2004.

SAS INSTITUTE INC. System for linear models. Cary: SAS Institute, 1986. 211p.

SCHWARZ, F.J.; SCHAMS, D.; ROPKE, R.; KIRCHGESSNER, M.; KOGEL, J.; MATZKE, P. Effects of somatotropin treatment on growth performance, carcass traits, and the endocrine system in finishing beef heifers. Journal of Animal Science, Albany, v.71, p.2721-2731, 1993. 
SILVA, J.V.; CARDOSO, D.; GUIMARAES, D.A.; LE PENDU, Y.; ALBUQUERQUE, N.I.; OHASHI, O.M. Estudo da biologia reprodutiva de fêmeas de caititu (Tayassu tajacu) criadas em cativeiro. Revista Brasileira de Reprodução Animal, Belo Horizonte, supl. 5, p.180-182, 2002.

SILVA, F.N.; PINHEIRO, M.J.P.; BEZERRA NETO, F.; BRAGA, A.P. Características da carcaça e análise químico-bromatológica da carne de catetos (Tayassu tajacu) submetidos a quatro níveis de proteína bruta em condições de cativeiro. Caatinga, Mossoró, v.15, n.1/2, p.57-60, 2002.

SILVA, J.V.; DIAS, H.L.; ALBUQUERQUE, N.I.; NEGRÃO, A.M.G. Brucelose, Leptospirose e tuberculose em caititu (Tayassu tajacu) criados em cativeiro. In: CONGRESSO BRASILEIRO DE MEDICINA VETERINÁRIA, 28., 2001, Salvador. Resumos... Salvador, 2001. p.12-13.

SILVEIRA, E.T.F. Técnicas de abate e seus efeitos na qualidade da carne suína. 1997. 226 f. Tese (Doutorado) - Faculdade de Engenharia de Alimentos, Universidade Estadual de Campinas, Campinas, 1997.

SMEDES, F.; THOMASEN, T. K. Evaluation of the Bligh and Dyer lipid determination method. Marine Pollution Bulletin, Oxon, v.32, n.8/9, p.681-688, 1996.

SOUZA, X.R. Efeitos de grupo genético, sexo e peso ao abate na qualidade de carne de cordeiros em crescimento. 2001. 116 f. Dissertação (Mestrado) Universidade Federal de Lavras, Lavras, 2001.

SOWLS, L.K. The peccaries. Tucson: University of Arizona Press, 1984.

SOWLS, L.K. Javelinas and other Peccaries: Their biology, management, and use. 2.ed. Tucson: University of Arizona Press, 1997.

UTILIZAÇÕES do babaçu. Disponível em: <http://ruralnews.terra.com.br/agricultura/outras/babaçu utilizacoes.htm>. Acesso em: 14 fev. 2002 
VEIGA, J.B.; TOURRAND, J.F.; QUANZ, D. Agro-pecuária na Transamazônica. O caso do município de Uruará. Documento de Pesquisa. EMBRAPA, Belém, p.1-54, 1995.

VENTURIERI, B. Padrões de atividades do caititu (Tayassu tajacu) em cativeiro. 2002. Dissertação (Mestrado) - Centro de Filosofia e Ciências Humanas, Universidade Federal do Pará, Belém, 2002.

WAHLGREN, N.M.; DEVINE, C.E.; TORNBERG, E. The influence of different pH time courses during rigor development on beef tenderness. In: INTERNACIONAL CONGRESS OF MEAT SCIENCE AND TECHNOLOGY, 43., 1997, Auckland. Anais... Auckland: ICOMST, 1997. 


\section{APÊNDICE}

APÊNDICE 1 - Ganho diário de peso (GDP) dos catetos em fase inicial de reprodução testando diferentes níveis de inclusão da amêndoa de babaçu integral nas rações

\begin{tabular}{cccc}
\hline Animal & Tratamento & Blocos & GDP $(\mathrm{g})$ \\
\hline 3 & A & 1 & 0,008 \\
4 & A & 2 & 0,005 \\
7 & A & 3 & 0,008 \\
2 & B & 1 & 0,006 \\
6 & B & 2 & $-0,004$ \\
12 & B & 3 & 0,035 \\
5 & C & 1 & 0,003 \\
9 & C & 2 & $-0,004$ \\
10 & C & 3 & $-0,001$ \\
1 & D & 1 & $-0,023$ \\
8 & D & 2 & $-0,002$ \\
11 & D & 3 & - \\
\hline
\end{tabular}

APÊNDICE 2 - Consumo diário (g) de catetos em fase inicial de reprodução testando diferentes níveis de inclusão da amêndoa de babaçu integral nas rações

\begin{tabular}{cccc}
\hline Animal & Tratamento & Blocos & Consumo \\
\hline 3 & A & 1 & 317,04 \\
4 & A & 2 & 357,18 \\
7 & A & 3 & 304,54 \\
2 & B & 1 & 318,36 \\
6 & B & 2 & 296,22 \\
12 & B & 3 & 387,68 \\
5 & C & 1 & 277,68 \\
9 & C & 2 & 272,22 \\
10 & C & 3 & 241,31 \\
1 & D & 1 & 134,44 \\
8 & D & 2 & 240,86 \\
11 & D & 3 & - \\
\hline
\end{tabular}


APÊNDICE 3- Ganho diário de peso dos catetos em fase de terminação testando diferentes níveis de inclusão da torta de babaçu nas rações

\begin{tabular}{cccc}
\hline Animal & Tratamento & Blocos & GDP $(\mathrm{g})$ \\
\hline 160 & A & 1 & 39 \\
197 & A & 2 & 27 \\
148 & A & 3 & 32 \\
23 & B & 1 & 43 \\
40 & B & 2 & 38 \\
128 & B & 3 & 33 \\
38 & C & 1 & 37 \\
97 & C & 2 & 39 \\
151 & C & 3 & 58 \\
183 & D & 1 & 41 \\
199 & D & 2 & 26 \\
45 & D & 3 & 44 \\
\hline
\end{tabular}

APÊNDICE 4- Consumo diário (g) de catetos em fase de terminação testando diferentes níveis de inclusão da torta de babaçu nas rações

\begin{tabular}{cccc}
\hline Animal & Tratamento & Blocos & Consumo \\
\hline 160 & A & 1 & 349,29 \\
197 & A & 2 & 320,14 \\
148 & A & 3 & 397,32 \\
23 & B & 1 & 373,69 \\
40 & B & 2 & 338,34 \\
128 & B & 3 & 365,31 \\
38 & C & 1 & 365,63 \\
97 & C & 2 & 323,59 \\
151 & C & 3 & 379,08 \\
183 & D & 1 & 386,47 \\
199 & D & 2 & 348,94 \\
45 & D & 3 & 351,26 \\
\hline
\end{tabular}


APÊNDICE 5- Parâmetros de carcaça de catetos abatidos na fase de terminação testando diferentes níveis de inclusão da torta de babaçu nas rações

\begin{tabular}{cccccccccc}
\hline Animal & Tratam & Blocos & CQ & CF & Comp. & Sangue & Couro & P T & PD \\
\hline 160 & A & 1 & 9100 & 9009 & 23 & 130 & 1875 & 125 & 120 \\
197 & A & 2 & 9100 & 9009 & 23,8 & 215 & 1975 & 125 & 125 \\
148 & A & 3 & 9500 & 9405 & 21 & 100 & 2415 & 120 & 120 \\
23 & B & 1 & 7500 & 7425 & 21 & 190 & 1820 & 115 & 120 \\
40 & B & 2 & 8900 & 8811 & 21,9 & 205 & 1765 & 135 & 125 \\
128 & B & 3 & 8400 & 8316 & 21 & 240 & 2090 & 115 & 120 \\
38 & C & 1 & 8200 & 8118 & 21 & 130 & 1705 & 135 & 120 \\
97 & C & 2 & 10200 & 10098 & 20,9 & 290 & 2005 & 125 & 115 \\
151 & C & 3 & 10100 & 9999 & 20 & 230 & 2285 & 130 & 125 \\
183 & D & 1 & 10000 & 9900 & 18 & 125 & 2150 & 125 & 125 \\
199 & D & 2 & 9100 & 9009 & 22 & 236 & 1710 & 110 & 115 \\
45 & D & 3 & 9400 & 9306 & 22 & 250 & 2080 & 115 & 120 \\
\hline
\end{tabular}

pesos em g, comprimento em cm;CQ: carcaça quente; CF: carcaça fria; Comp.: comprimento; PT: patas traseiras; PD: patas dianteiras

APÊNDICE 6- Peso em gramas de órgãos e glândulas de catetos abatidos após a fase de terminação testando diferentes níveis de inclusão da torta de babaçu nas rações

\begin{tabular}{cccccccccc}
\hline Animal & Tratam & Blocos & Estom & Coraç & Pulm & Figado & Baço & Rins & Intes \\
\hline 160 & A & 1 & 545 & 55 & 140 & 175 & 160 & 45 & 470 \\
197 & A & 2 & 495 & 60 & 115 & 205 & 85 & 50 & 490 \\
148 & A & 3 & 350 & 75 & 110 & 195 & 55 & 45 & 675 \\
23 & B & 1 & 445 & 75 & 170 & 230 & 65 & 50 & 710 \\
40 & B & 2 & 340 & 55 & 145 & 195 & 45 & 40 & 525 \\
128 & B & 3 & 375 & 55 & 140 & 245 & 80 & 60 & 785 \\
38 & C & 1 & 550 & 65 & 140 & 245 & 75 & - & 800 \\
97 & C & 2 & 430 & 65 & 140 & 210 & 60 & 55 & 615 \\
151 & C & 3 & 470 & 65 & 140 & 245 & 60 & 70 & 615 \\
183 & D & 1 & 365 & 45 & 110 & 215 & 60 & - & 550 \\
199 & D & 2 & 515 & 55 & 130 & 200 & - & 55 & 610 \\
45 & D & 3 & 245 & 60 & 105 & 205 & 60 & 55 & 690 \\
\hline
\end{tabular}

Estom= estômago; Coraç= coração; Pulm= pulmão; Intes= intestino 
APÊNDICE 7- Peso em gramas de cortes comerciais de catetos abatidos após a fase de terminação testando diferentes níveis de inclusão da torta de babaçu nas rações

\begin{tabular}{ccccccc}
\hline Animal & Tratamento & Blocos & Costela & Paleta & Pernil & \%Pernil \\
\hline 160 & A & 1 & 1205 & 1100 & 1305 & 31,07 \\
197 & A & 2 & 830 & 905 & 1535 & 31,32 \\
148 & A & 3 & 1925 & 895 & 1445 & 29,48 \\
23 & B & 1 & 1285 & 865 & 1220 & 28,37 \\
40 & B & 2 & 1060 & 970 & 1535 & 28,42 \\
128 & B & 3 & 1095 & 1025 & 1505 & 40,67 \\
38 & C & 1 & 955 & 1115 & 1580 & 41,57 \\
97 & C & 2 & 1310 & 815 & 1280 & 27,82 \\
151 & C & 3 & 1175 & 900 & 1545 & 36,78 \\
183 & D & 1 & 1490 & 965 & 1465 & 32,55 \\
199 & D & 2 & 1430 & 1025 & 1580 & 41,57 \\
45 & D & 3 & 1320 & 1095 & 1620 & 37,67 \\
\hline
\end{tabular}

APÊNDICE 8- Peso vivo, perdas de peso e rendimento de carcaça de catetos abatidos após a fase de terminação testando diferentes níveis de inclusão da torta de babaçu nas rações

\begin{tabular}{cccccrc}
\hline Animal & Tratamento & Blocos & Peso Vivo Peso Jejum & RCQ\% & RCF\% \\
\hline 160 & A & 1 & 15900 & 16000 & 56,87 & 56,31 \\
197 & A & 2 & 16300 & 16300 & 55,82 & 55,27 \\
148 & A & 3 & 17400 & 17100 & 55,55 & 55,00 \\
23 & B & 1 & 14300 & 14200 & 52,81 & 52,29 \\
40 & B & 2 & 14300 & 14700 & 60,54 & 59,94 \\
128 & B & 3 & 18300 & 18200 & 46,15 & 45,69 \\
38 & C & 1 & 15100 & 14700 & 55,78 & 55,22 \\
97 & C & 2 & 17100 & 17100 & 59,64 & 59,05 \\
151 & C & 3 & 17600 & 17400 & 58,04 & 57,47 \\
183 & D & 1 & 17000 & 16400 & 60,97 & 60,37 \\
199 & D & 2 & 16600 & 16400 & 55,48 & 54,93 \\
45 & D & 3 & 15100 & 15200 & 61,84 & 61,22 \\
\hline
\end{tabular}

pesos em g; RCQ: Rendimento de carcaça quente em relação ao peso em jejum RCF: Rendimento de carcaça fria em relação ao peso em jejum 
APÊNDICE 9 - Peso em gramas de ossos, músculo e gordura de costelas de catetos abatidos após a fase de terminação testando diferentes níveis de inclusão da torta de babaçu nas rações

\begin{tabular}{ccccccc}
\hline Animal & Tratamento & Blocos & Ossos & Músculo & Gordura & Total \\
\hline 160 & A & 1 & 7,80 & 51,34 & 6,83 & 65,97 \\
197 & A & 2 & 10,67 & 64,61 & 9,93 & 85,21 \\
148 & A & 3 & 8,26 & 56,26 & 13,84 & 78,36 \\
23 & B & 1 & 8,00 & 30,39 & 8,38 & 46,77 \\
40 & B & 2 & 10,52 & 66,16 & 5,01 & 81,69 \\
128 & B & 3 & 10,97 & 83,39 & 11,27 & 105,63 \\
38 & C & 1 & 7,58 & 37,82 & 6,07 & 51,47 \\
97 & C & 2 & 9,74 & 47,42 & 5,92 & 63,08 \\
151 & C & 3 & 11,47 & 67,13 & 7,70 & 86,30 \\
183 & D & 1 & 9,36 & 48,61 & 8,98 & 66,95 \\
199 & D & 2 & 12,13 & 57,36 & 8,41 & 77,90 \\
45 & D & 3 & 11,03 & 96,05 & 12,66 & 119,74 \\
\hline
\end{tabular}

APÊNDICE 10- Análise química bromatológica de costelas de catetos abatidos após a fase de terminação testando diferentes níveis de inclusão da torta de babaçu nas rações

\begin{tabular}{cccccc}
\hline Animal & Tratamento & $\begin{array}{c}\text { MS } 100^{\circ} \mathrm{C} \mathrm{g} / \mathrm{kg} \\
\text { MF }\end{array}$ & MM g/kg MS & EE g/kg MS & PB g/kg MS \\
\hline 160 & A & 983,31 & 178,96 & 157,86 & 485,25 \\
197 & A & 989,22 & 128,02 & 124,80 & 645,78 \\
148 & A & 969,17 & 128,64 & 143,03 & 680,96 \\
23 & B & 987,94 & 125,92 & 299,95 & 538,47 \\
40 & B & 986,52 & 125,56 & 70,96 & 622,06 \\
128 & B & 991,58 & 108,73 & 200,31 & 591,52 \\
38 & C & 985,49 & 180,91 & 118,60 & 640,54 \\
97 & C & 985,72 & 216,64 & 121,32 & 628,01 \\
151 & C & 987,10 & 206,31 & 106,63 & 647,29 \\
183 & D & 986,75 & 178,10 & 147,17 & 637,95 \\
199 & D & 983,77 & 161,98 & 185,85 & 572,02 \\
45 & D & 989,56 & 190,06 & 126,28 & 776,79 \\
\hline
\end{tabular}

$\mathrm{MS}=$ matéria seca; $\mathrm{MF}=$ matéria fresca; $\mathrm{MM}=$ matéria mineral; $\mathrm{EE}=$ extrato etéreo; $\mathrm{PB}=$ proteína bruta 
APÊNDICE 11- Propriedades da carne de catetos abatidos após a fase de terminação testando diferentes níveis de inclusão da torta de babaçu nas rações

\begin{tabular}{ccccccc}
\hline Animal & Tratamento & Blocos & Perda Peso & Fcisal & PH & CRA \\
\hline 160 & A & 1 & 18,18 & 3,02 & 6,27 & 60,58 \\
197 & A & 2 & 10,82 & 2,76 & 6,45 & 61,56 \\
148 & A & 3 & 16,22 & 10,20 & 5,89 & 59,96 \\
23 & B & 1 & 23,93 & 3,27 & 6,37 & 64,14 \\
40 & B & 2 & 18,77 & 3,53 & 6,40 & 61,71 \\
128 & B & 3 & 23,50 & 3,41 & 6,22 & 63,34 \\
38 & C & 1 & 19,23 & 2,53 & 6,61 & 61,73 \\
97 & C & 2 & 21,46 & 6,30 & 5,99 & 59,56 \\
151 & C & 3 & 15,70 & 4,37 & 6,28 & 58,70 \\
183 & D & 1 & 15,68 & 3,79 & 6,04 & 59,19 \\
199 & D & 2 & 16,49 & 5,08 & 6,38 & 63,35 \\
45 & D & 3 & 22,71 & 4,30 & 6,26 & 61,60 \\
\hline
\end{tabular}

Fcisal= força de cisalhamento

$\mathrm{CRA}=$ Capacidade de retenção de água 